\title{
1. Financial regulation and civil liability in European law: towards a more coordinated approach? \\ Olha O. Cherednychenko
}

\section{SETTING THE SCENE}

The title of this book unites two distinct but nevertheless closely interrelated legal concepts in the legal order of the European Union (EU) - financial regulation and civil liability. While these categories may have intuitive appeal, defining them is not entirely straightforward. Financial regulation is commonly associated with a set of ex ante rules imposed by government on the financial sector in the public interest and accompanied by mechanisms of public supervision and enforcement, usually by administrative agencies, to deter violations. In contrast to this sector-specific public regulation, civil liability has traditionally been conceived as an ex post remedy in contract or tort that can be relied upon by the aggrieved party against the wrongdoer, typically before a civil court, to obtain compensation for damage suffered. As such, civil liability is a major corrective tool of private law, which primarily seeks to ensure the balance between the interests of private individuals through their respective rights and remedies.

Yet, a strict functional separation between financial regulation and civil liability along these lines is not reflected in the current legal framework for financial markets, which has been profoundly shaped by EU law. Even though there is no general EU competence to harmonise national private law, the EU legislator has widely used traditional private law concepts, such as civil liability, as regulatory instruments in the pursuit of policy objectives based on Article 114 of the Treaty on the Functioning of the European Union (TFEU). Apart from the overarching goal of establishing and ensuring the functioning of the internal market, these include, for instance, financial stability, market efficiency, and consumer protection. The oxymoron 'European regulatory 
private law" - a concept used to refer to the EU measures of a regulatory nature that affect private law relationships - aptly captures this point. It is manifest in many harmonised areas, such as consumer law, non-discrimination law, competition law, environmental law, public procurement law, and financial law. Furthermore, according to the well-established case law of the Court of Justice of the European Union (CJEU), where EU law creates individual rights, these have to be complemented by remedies, which must be effective, proportionate, and dissuasive. ${ }^{2}$ In this context, the CJEU has explicitly recognised the deterrent function of private law remedies, including civil liability, in dissuading potential wrongdoers from committing infringements. ${ }^{3}$

Within the EU scheme of financial market regulation, civil liability thus functions not only as a compensatory device to correct the wrong committed by one private individual against another. In addition, it also has a regulatory function, serving as a deterrent against violations of the standards set by the EU legislator with a view to achieving certain policy goals. In fact, it is the regulatory dimension of civil liability - and that of private law more generally - rather than its compensatory function that EU law is primarily concerned with. After all, the main question posed by the EU legislator has been not how to ensure interpersonal justice between financial market participants, but rather how to make financial markets, and thence the internal market as a whole, function better. ${ }^{4}$

\footnotetext{
1 H.-W. Micklitz, 'The Visible Hand of European Regulatory Private Law' (2009) 28 YEL 3.

2 See, e.g., F. Cafaggi \& P. Iamiceli, 'The Principles of Effectiveness, Proportionality and Dissuasiveness in the Enforcement of EU Consumer Law: The Impact of a Triad on the Choice of Civil Remedies and Administrative Sanctions' (2017) 25 ERPL 575.

See, e.g., Case 14/83, Von Colson, ECLI:EU:C:1984:153, para. 23; Case C-453/99, Courage Ltd, ECLI:EU:C:2001:465, para. 27; Case C-618/10, Banco Español de Crédito SA, ECLI:EU:C:2012:349, para. 69; Case C-174/12, Hirmann v. Immofinanz $A G$, ECLI:EU:C:2013:856, paras 43-44; Joined Cases C-154/15 and C-307/15, Francisco Gutiérrez Naranjo, ECLI:EU:C:2016:980, paras 61-63. See also, e.g., G. Wagner, 'Punitive Damages in European Private Law' in J. Basedow et al. (eds), Max Planck Encyclopedia of European Private Law (OUP 2012) 1406.

${ }_{4}$ Cf., e.g., H.-W. Micklitz, The Politics of Justice in European Private Law: Social Justice, Access Justice, Societal Justice (CUP 2018); H. Collins, 'The Revolutionary Trajectory of EU Contract Law towards Post-national Law' in S. Worthington et al. (eds), Revolution and Evolution in Private Law (Hart 2018) 315, at 318 et seq.; M.W. Hesselink, 'European Contract Law: A Matter of Consumer Protection, Citizenship, or Justice?' (2007) 15 ERPL 323; O.O. Cherednychenko, 'Private Law Discourse and Scholarship in the Wake of the Europeanisation of Private Law' in J. Devenney and M.B. Kenny (eds), The Transformation of European Private Law: Harmonisation, Consolidation, Codification or Chaos? (CUP 2013) 148.
} 
The entanglement between public regulation and private law in the sphere of EU law in turn has prompted or fostered major changes in the institutional division of labour in the enforcement domain. Traditionally, administrative agencies focussed exclusively on deterrence-oriented enforcement of applicable standards through public law means, such as punitive fines, whereas civil courts served as the main venues for private enforcement, in particular through civil liability lawsuits by plaintiffs seeking compensation. For the enforcement of its standards, however, EU law relies on multiple avenues which do not necessarily fit into this conventional conception. In particular, to ensure a high level of consumer protection, the EU legislator has actively promoted extra-judicial enforcement by alternative dispute resolution (ADR) entities, thus pushing for a move away from litigation before civil courts. ${ }^{5}$ When deciding individual disputes between financial firms and consumers, ADR bodies may hold the firms liable out of court for the damage suffered by the consumers as a result of the breach of regulatory standards with a European origin. In so doing, ADR entities not only act as quasi-judicial bodies, providing compensation for aggrieved individuals, but, especially in mass damage cases, also perform a quasi-regulatory function, helping to improve deterrence. In addition, recent experience has shown that when enforcing EU or national financial regulation, some administrative agencies no longer only pursue deterrence, but also secure compensation. ${ }^{6}$ Such practices give rise to hybrid enforcement mechanisms whereby the regulatory and compensatory functions of public and private enforcement are performed by one and the same authority. In this context, it has been argued that the enforcement of European private law has become a regulated market for dispute resolution where providing justice to consumers is a service. ${ }^{7}$ Although the ultimate enforcement authority remains vested in state institutions, different actors, such as courts, ADR entities, and administrative agencies, compete with each other in such a market.

Against the backdrop of this regulatory and enforcement landscape, the essays collected in this work address the interplay between financial regulation and civil liability in European law, understood in the broad sense

5 H.-W. Micklitz, 'The Transformation of Enforcement in European Private Law: Preliminary Considerations' (2015) 23 ERPL 491, at 508; O.O. Cherednychenko, 'Public and Private Enforcement of European Private Law in the Financial Services Sector' (2015) 23 ERPL 621, at 638.

6 Cherednychenko (n. 5) at 643; C. Hodges \& N. Creutzfeldt, 'Transformations in Public and Private Enforcement' in H.-W. Micklitz \& A. Wechsler (eds), The Transformation of Enforcement: European Economic Law in a Global Perspective (Hart 2016) 115, at 120.

7 A. Wechsler \& B. Tripković, 'Conclusions: Enforcement in Europe as a Market of Justice' in H.-W. Micklitz \& A. Wechsler (eds), The Transformation of Enforcement: European Economic Law in a Global Perspective (Hart 2016) 377. 
of EU law and national law within its scope. The regulatory potential of private law, in general, and civil liability, in particular, as opposed to that of public regulation has been extensively analysed with respect to national legal systems, especially following the rise of the regulatory state. ${ }^{8}$ Scholarly work on European private law has also drawn attention to this issue, exploring it in the context of the EU harmonisation of national laws. ${ }^{9}$ The established line of enquiry suggests that, in order to prevent damage from occurring in the first place but, at the same time, to indemnify the victims once it has occurred, ex ante public regulation and ex post civil liability need to be combined. Within this framework, civil liability can perform not only a compensatory, but also a deterrent function, providing additional incentives for potential offenders to comply with regulatory and/or private law standards. In particular, by exercising their civil liability rights, whether contractual or otherwise, customers can promote responsible, customer-oriented, behaviour of financial firms. ${ }^{10}$ This points to the important role that civil liability can play within a particular regulatory scheme, and to the need for some form of coordination between public and private law instruments and enforcement mechanisms. However, at present, the legal framework for such coordination is underdeveloped and under-investigated, particularly in the context of EU law. So far, scholarly work has mainly focussed on the private law implications of EU financial regulation in specific areas ${ }^{11}$ rather than on an overarching perspective on the interplay between public regulation and civil liability in the European financial law as a whole. This volume aims to provide such a perspective, focussing on the role of civil liability as a regulatory and compensatory tool in the EU multi-level system of governance for financial markets.

The book is principally concerned with two key questions. First, it seeks to examine whether there is a coordinated approach to financial regulation and civil liability in European law. In particular, is such an approach manifest across (a) different sectors of financial services and activities (such as

8 See, e.g., H. Collins, Regulating Contracts (OUP 1999); P. Schuck (ed.), Tort Law and the Public Interest: Competition, Innovation and Consumer Welfare (WW Norton \& Co 1991); C. Parker et al. (eds), Regulating Law (OUP 2004).

9 See, e.g., F. Cafaggi \& H. Muir Watt (eds), The Regulatory Function of European Private Law (Edward Elgar Publishing 2009).

10 Cf. N. Moloney, 'Effective Policy Design for the Retail Investment Services Market: Challenges and Choices Post FSAP' in G. Ferrarini \& E. Wymeersch (eds), Investor Protection in Europe: Corporate Law Making, the MiFID and Beyond (OUP 2006) 381, at 425.

11 See, e.g., D. Busch \& D.A. DeMott (eds), Liability of Asset Managers (OUP 2012); D. Busch et al. (eds), Prospectus Regulation and Prospectus Liability (OUP 2021); S. Grundmann \& P. Sirena (eds), European Contract Law in the Banking and Financial Union (Intersentia 2021, forthcoming). 
payments, credit, and securities) and (b) the various actors involved in public, private, and hybrid enforcement (such as courts, ADR bodies, and financial regulators)? Second, the book addresses the issue of whether a more coordinated approach along these lines should be developed and, if so, how the EU and its Member States can contribute thereto. In order to answer these questions, the contributions in this volume map and critically analyse the interface between EU financial regulation and civil liability within and across specific areas of financial services and activities. The study includes the traditional legal, comparative and economic analysis of this issue, as well as insights from an experimentalist governance perspective. While the EU and national legal systems of the current (e.g., Belgium, Germany, and the Netherlands) and former (UK) Member States have been the main focus of the study, the US experience in the securities field has also been considered.

The volume comprises 13 chapters and is divided into four parts. Part I sets out a general framework within which we explore the interplay between EU financial regulation and civil liability. It contains this framing chapter, which presents the overall design and major findings of the study, as well as the chapters that examine the book's theme through three different lenses: EU law, law and economics, and experimentalist governance. Part II explores the interface between financial regulation and civil liability in the areas of payments and credit (including both simple consumer credit and mortgage credit), focussing on the liability of financial firms providing the respective services. Part III proceeds to examine such interface in the securities field. It offers a general overview of the place of civil liability in this vast and rapidly evolving area and focusses specifically on the liability of credit rating agencies and investment firms. Finally, the chapters included in Part IV delve into the issue of the civil liability of financial regulators in the event of a bank's resolution and that of private ADR entities for non-performance of their services - two largely unexplored avenues for enhancing the role of civil liability in the regulatory sphere.

\section{2 \\ THE LEGAL MATRIX FOR RELATIONSHIPS BETWEEN PRIVATE PARTIES IN THE EU FINANCIAL SECTOR}

To understand the relationship between EU financial regulation and civil liability, we should first take a moment to consider more carefully the legal matrix for relationships between private parties in the financial sector within the EU multi-level system of governance. Traditionally, the interactions between banks and clients, credit rating agencies and investors, or between financial firms were the exclusive province of national private law. Nowadays, however, EU financial regulation increasingly determines how financial firms should behave in the contractual and extra-contractual domains. For 
example, the EU Markets in Financial Instruments Directive II (MiFID II) ${ }^{12}$ and the Markets in Financial Instruments Regulation (MiFIR), ${ }^{13}$ adopted in the wake of the global financial crisis of 2007-2008 to replace MiFID I, ${ }^{14}$ pose significant limits to freedom of contract in making standard contract terms for investment products, distribution agreements, and investment service contracts. Similarly, the Credit Rating Agencies (CRA) Regulation ${ }^{15}$ obliges credit rating agencies to ensure that the issuing of a credit rating is not affected by conflicts of interest.

Furthermore, while EU law historically created rights and the Member States were to provide for remedies, today both the EU legislator and the CJEU profoundly shape enforcement mechanisms at EU and national level. ${ }^{16}$ The procedural autonomy of the Member States in the field of financial law has been progressively limited by EU horizontal and sector-specific measures in two major respects. First, the EU legislator has principally relied on the public enforcement model to ensure compliance with financial regulation, profoundly restricting national procedural autonomy in the realm of administrative law. For example, under the Consumer Protection Cooperation Regulation ${ }^{17}$ and a number of sector-specific measures, such as MiFID I and MiFID II, Member States are required to equip administrative agencies with powers in the realm of consumer/retail investor protection. The public enforcement model has received a major boost in the wake of the financial crisis, with a greater centralisation of financial supervision at EU level through the establishment of the European System of Financial Supervision (ESFS) and the creation of the Banking Union. ESFS is a network of financial regulators that aims to ensure consistent and appropriate financial supervision throughout the EU. Apart

12 Directive 2014/65/EU of the European Parliament and of the Council of 15 May 2014 on markets in financial instruments (recast) [2014] OJ L173/349 (MiFID II).

13 Regulation (EU) No 600/2014 of the European Parliament and of the Council on markets in financial instruments [2014] OJ L173/84 (MiFIR).

14 Directive 2004/39/EC of the European Parliament and of the Council of 21 April 2004 on markets in financial instruments [2004] OJ L145/1 (MiFID I).

15 Regulation (EC) No 1060/2009 of the European Parliament and of the Council of 16 September 2009 on credit rating agencies [2009] OJ L302/1, as amended by Regulation (EU) No 513/2011 of the European Parliament and of the Council of 11 May 2011 [2011] OJ L145/30 and Regulation (EU) 462/2013 of the European Parliament and of the Council of 21 May 2013 [2013] OJ L146/1 (these three regulations are referred to as the CRA Regulation).

16 On this development, see O.O. Cherednychenko, 'Public and Private Enforcement of European Private Law: Perspectives and Challenges' (Editorial Special Issue) (2015) 23 ERPL 481.

17 Regulation (EU) 2017/2394 of the European Parliament and of the Council of 12 December 2017 on cooperation between national authorities responsible for the enforcement of consumer protection laws [2017] OJ L345/1. 
from national supervisory authorities, it includes three sectoral European Supervisory Authorities (ESAs) - the European Banking Authority (EBA), the European Securities and Markets Authority (ESMA), and the European Insurance and Occupational Pensions Authority (EIOPA) - and the European Systemic Risk Board (ESRB). The Banking Union is designed to strengthen banks and ensure more effective banking supervision in the EU through the Single Supervisory Mechanism (SSM) and the Single Resolution Mechanism (SRM). Again, both mechanisms comprise not only national but also supranational financial regulators. While within the SSM the European Central Bank (ECB) is charged with certain supervisory tasks in respect of the EU financial system, including direct supervision of most significant eurozone banks, the SRM places responsibility on the Single Resolution Board (SRB) to ensure an orderly resolution of failing banks. As the European banking supervisor, the ECB cooperates closely with the ESAs, especially the EBA.

The rise of public supervision and enforcement by EU and national administrative agencies - a process known as 'agencification' 18 - has led to the development of a hybrid legal order which can be called 'European financial supervision private law'. ${ }^{19}$ I use this oxymoron to describe any body of regulatory conduct of business rules with a European origin, to be observed by financial firms in the contractual or non-contractual domain, which forms part of a framework for public supervision over financial markets in the EU. From a legal-technical point of view, European financial supervision private law rules concern the relationship between a particular financial firm and an administrative agency entrusted with the supervisory and enforcement tasks, and thus do not belong to the realm of traditional private law, particularly contract and tort law. At the same time, such rules set standards of behaviour for the relationship between financial firms and other professional or non-professional private parties and often aim to protect the latter. In essence, therefore, European financial supervision private law affects the relationships between private actors and can thus be considered as quasi private.

Second, the procedural autonomy of the Member States in the field of financial law has also been limited in the private enforcement domain. Although the EU legislator has primarily focussed on public supervision and

18 See, e.g., M. Scholten \& M. van Rijsbergen, 'The Limits of Agencification in the European Union' (2014) 15 GLJ 1223.

19 O.O. Cherednychenko, 'Public Supervision over Private Relationships: Towards European Supervision Private Law?' (2014) 22 ERPL 37. See also H.-W. Micklitz, 'The Public and the Private - European Regulatory Private Law and Financial Services' (2014) 10 ERCL 473; O.O. Cherednychenko, 'Financial Consumer Protection in the EU: Towards a Self-Sufficient European Contract Law for Consumer Financial Services?' (2014)10 ERCL 476. 
enforcement, it has also increasingly recognised the importance of private enforcement and has been particularly keen to promote individual consumer redress out of court. Two measures with a wide scope of application - the Consumer ADR Directive ${ }^{20}$ and the Consumer Online Dispute Resolution (ODR) Regulation ${ }^{21}$ - have been adopted with a view to ensuring consumer protection in out-of-court proceedings. The Consumer ADR Directive seeks to ensure that consumers have access to proper ADR entities in both domestic and cross-border contractual disputes arising out sales or service (including financial service) contracts with traders. The Consumer ODR Regulation establishes an ODR platform in the form of an interactive website at EU level, which provides consumers with access to ADR schemes in disputes arising from online transactions. The European Commission has also established FIN-NET - a network of organisations responsible for out-of-court settlement of consumer complaints in the field of financial services - designed to promote cooperation between ADR entities and provide consumers with easy access to ADR procedures in cross-border disputes with financial firms. Further, many sector-specific EU measures, such as MiFID II, require the Member States to establish efficient and effective complaints and redress procedures for the out-of-court settlement of consumer disputes.

In addition, the European Commission also seeks to foster collective consumer redress through representative actions before national courts or administrative authorities. Its recent proposal to this effect aims, in particular, to bring a number of specific sectors, including financial services, within the scope of the injunction procedure and introduce collective compensatory redress mechanisms that would allow qualified entities to seek a redress order or a declaratory decision regarding the firm's liability towards the consumers harmed by an infringement of EU law. ${ }^{22}$

These developments in the EU regulatory and enforcement landscape, most notably the growing importance of public regulation, supervision and enforce-

20 Directive 2013/11/EU of the European Parliament and of the Council of 21 May 2013 on alternative dispute resolution for consumer disputes [2013] OJ L165/63 (Consumer ADR Directive).

${ }^{21}$ Regulation (EU) No 524/2013 of the European Parliament and of the Council of 21 May 2013 on online dispute resolution for consumer disputes [2013] OJ L165/1 (Consumer ODR Regulation).

22 European Commission, Proposal for a Directive of the European Parliament and of the Council on representative actions for the protection of the collective interests of consumers, $\operatorname{COM}(2018) 184$ final. See also European Commission, Communication for the Commission to the European Parliament, the Council and the European Economic and Social Committee 'A New Deal for Consumers', COM(2018) 183 final. On this initiative, see I. Benöhr, 'Collective Redress in the Financial Sector and the New EU Deal for Consumers’ (2019) 27 ERPL 1345. 
ment in the private law domain, have resulted in an overly complex legal matrix for relationships between private parties in the financial sector (see Figure 1.1). The main components of this matrix include EU financial regulation, national administrative law, and national private law. Further, multiple actors at EU and Member State level are involved in rule-making, ensuring compliance with and enforcement of multiple sets of rules. These include legislators, financial regulators (including three ESAs - EBA, ESMA, and EIOPA - and the ECB), courts (including the CJEU as well as national administrative and civil courts), ADR bodies, and the financial industry.

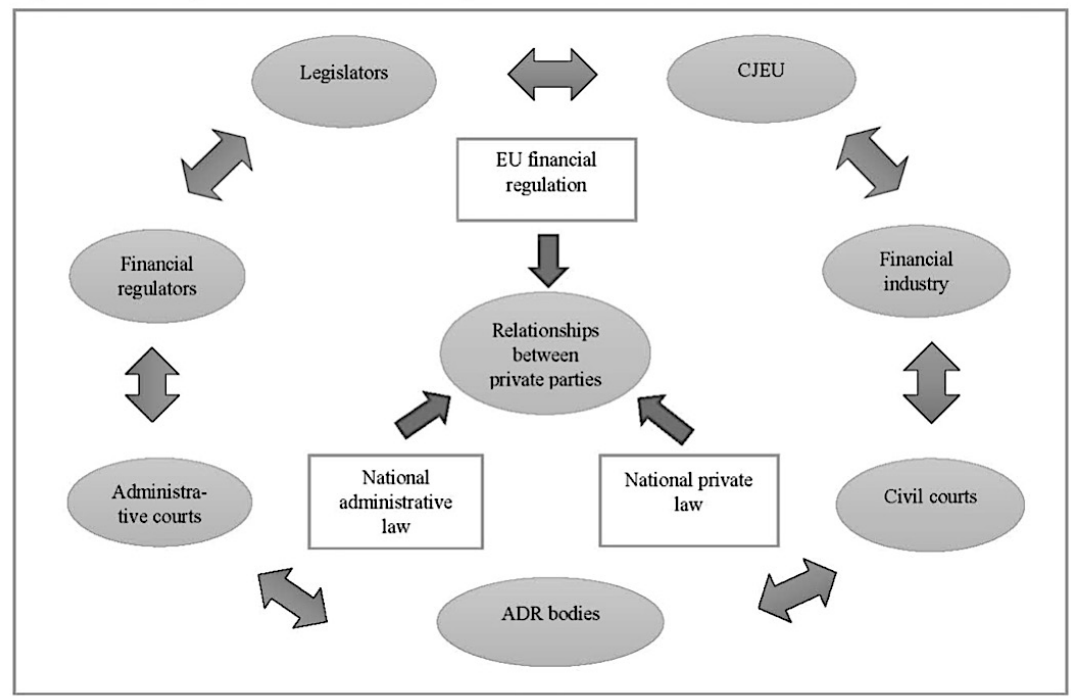

Source: $\quad$ O.O. Cherednychenko, 'Two Sides of the Same Coin: EU Financial Regulation and Private Law’ (2020) EBOR, forthcoming.

Figure 1.1 The legal matrix for relationships between private parties in the EU financial sector.

While financial regulation and private law have thus become closely intertwined, ${ }^{23}$ the disciplinary divide and silo mentality still profoundly affect

23 Cf., S. Grundmann, 'Privaatrecht und Regulierung' in H.C. Grigoleit \& R. Petersen (eds), Privatrechtsdogmatik im 21. Jahrhundert: Festschrift für Claus-Wilhelm Canaris zum 80. Geburtstag (De Gruyter 2017) 907, at 926. 
the academic discourse on financial services and activities in Europe where financial regulation (predominantly as part of public law) and private law are still largely studied separately. As Mads Andenas and Federico Della Negra observe: 'For a contract lawyer, an interest rate swap is a contract, but for an administrative lawyer, it is a financial instrument. ${ }^{24}$ The gap between financial regulation and private law is also manifest in the current EU policy discourse which has traditionally been concerned with economic activities of market participants (e.g., financial services) rather than the legal mechanisms that enable such activities (e.g., contracts) and enforcement avenues available to private parties. The post-crisis legal matrix for the financial sector in the EU is developing in a piecemeal fashion, combining elements of public and private law without a clear vision of how various bits and pieces actually fit together in the context of policy-making, standard-setting, and enforcement design. ${ }^{25}$

\section{THE INTERPLAY BETWEEN FINANCIAL REGULATION AND CIVIL LIABILITY IN EUROPEAN LAW}

The gap between financial regulation and private law in the EU policy discourse is most evident in the current enforcement landscape. Despite the rise of public enforcement, private judicial and extra-judicial enforcement by individuals and their groups remains necessary for EU financial regulation to achieve its policy goals. As already noted, civil liability may not only perform a compensatory function, but also act as an additional deterrent against breaches of regulatory standards. The EU legislator has fostered the development of effective procedures for out-of-court dispute resolution and collective action in the financial sector and beyond. At the same time, private law rights and remedies have not been central to the European enforcement architecture. Even though the CJEU has recognised the deterrent function of civil liability, much uncertainty still exists about the purport of the principle of dissuasiveness and its relationship with the principles of effectiveness and proportionality in a private law setting. ${ }^{26}$ While in some areas, such as consumer and competition law, EU secondary legislation has sought to harmonise contractual or non-contractual remedies for breach of EU law, overall, the role of private law remedies in the field of financial law has not received the same level of legislative attention.

24 M. Andenas \& F. Della Negra, 'Between Contract Law and Financial Regulation: Towards the Europeanisation of General Contract Law' (2017) 28 EBLR 499, at 505.

25 O.O. Cherednychenko, 'Two Sides of the Same Coin: EU Financial Regulation and Private Law' (2020) EBOR, forthcoming.

26 Cf. C. Pavillon, 'Private Enforcement as a Deterrence Tool: A Blind Spot in the Omnibus-Directive’ (2019) 27 ERPL 1297. 
Limited sensitivity of the EU regulatory scheme for financial markets to the private law dimension of the regulatory standards that it has brought about is reflected in the general lack of a coordinated approach to financial regulation and civil liability in European law. It is to this issue that we now turn.

\subsection{Cross-sector Coordination?}

The comparative legal analysis of EU measures in the field of financial law reveals major differences in how the EU legislator has dealt with the issue of civil liability across different sectors of financial services and activities. In his contribution to this volume, Takis Tridimas distinguishes between three main approaches. First, some EU measures are silent on private law rights and/or remedies. This legislative silence is manifest, for instance, in MiFID II, the Market Abuse Regulation ${ }^{27}$ and the Securitisation Regulation, ${ }^{28}$ which merely require or outlaw certain conduct and explicitly provide for an administrative enforcement mechanism. Another example of this approach is the Mortgage Credit Directive, ${ }^{29}$ which, following the structure of the Consumer Credit Directive ${ }^{30}$ is not only silent on the rights of consumers in case of breach of regulatory standards, but also on the enforcement mode more generally. In all such cases, the issue of whether a particular EU measure gives rise to private law rights and remedies becomes a matter of interpretation in the light of the EU doctrine of implied rights and the principles of effectiveness and equivalence. Second, there are also EU measures that make a general reference to national private law remedies. For instance, like its predecessor the Prospectus Directive, ${ }^{31}$ the Prospectus Regulation, ${ }^{32}$ which governs prospectus disclosures

27 Regulation (EU) No 596/2014 of the European Parliament and of the Council of 16 April 2014 on market abuse [2014] OJ L173/1 (Market Abuse Regulation).

28 Regulation (EU) 2017/2402 of the European Parliament and of the Council of 12 December 2017 laying down a general framework for securitisation and creating a specific framework for simple, transparent and standardised securitisation [2017] L347/45 (Securitisation Regulation).

29 Directive 2014/17/EU of the European Parliament and of the Council of 4 February 2014 on credit agreements for consumers relating to residential immovable property [2014] OJ L60/34 (Mortgage Credit Directive).

30 Directive 2008/48/EC of the European Parliament and of the Council of 23 April 2008 on credit agreements for consumers and repealing Council Directive 87/102/EEC [2008] OJ L133/66 (Consumer Credit Directive).

31 Directive 2003/71/EC of the European Parliament and of the Council of 4 November 2003 on the prospectus to be published when securities are offered to the public or admitted to trading [2003] OJ L345/64 (Prospectus Directive).

32 Regulation (EU) 2017/1129 of the European Parliament and of the Council of 14 June 2017 on the prospectus to be published when securities are offered to the public or admitted to trading on a regulated market [2017] OJ L168/12 (Prospectus Regulation). 
by issuers of securities, obliges Member States to ensure that their national laws on civil liability apply to those persons responsible for the information given in a prospectus. ${ }^{33}$ This provision leaves a wide margin of discretion to the Member States as to how to give effect to it, subject to the limited exceptions set out in the regulation itself concerning a prospectus summary, and the principles of effectiveness and equivalence. At the same time, an explicit reference to national law on civil liability included in the Prospectus Regulation serves to provide legal certainty for aggrieved investors about the existence of this private law remedy in case of violation of the EU prospectus rules. Third, some EU measures expressly provide for European private law rights and remedies. Within this category, one may distinguish sub-categories according to the type of remedy or the degree of its specificity. For example, the Payment Services Directive 2 (PSD2) ${ }^{34}$ provides for detailed liability rules on the allocation of losses resulting from fraud, forgery and error between payment service providers and users, thus leaving only a limited margin of discretion to the Member States. In contrast, a more general provision on civil liability has been included in the CRA Regulation. The latter explicitly grants investors and issuers a remedy to claim damages where a credit rating agency has committed, intentionally or with gross negligence, any of the infringements listed in this regulation, provided certain conditions are met. Yet the Member States have considerable room for manoeuvre to shape this European private law remedy because the CRA Regulation leaves the interpretation of all the material terms, such as 'damage', 'intention', or 'gross negligence', to national law.

This classification of EU measures according to the extent to which they engage with private law rights and remedies reflects the traditional stance of EU law, which has not, at least not explicitly, recognised the conceptual distinction between public and private law as it had developed in national legal systems. In line with this conventional understanding, Tridimas observes that the case law of the CJEU supports a hybrid model of enforcement. Under this model, EU law primarily relies on national remedies, which in turn are profoundly influenced by EU law, particularly through the principles of equivalence and effectiveness. In his view, the resulting hybridity of national remedies for breach of EU financial regulation - which to a greater or lesser extent is manifest in all three categories of EU measures in this area - blurs the boundaries between rights and remedies and in some respects neutralises the public/private divide. For the purpose of ensuring the effectiveness of

33 Prospectus Regulation, art. 11(2).

34 Directive (EU) 2015/2366 of the European Parliament and of the Council of 25 November 2015 on payment services in the internal market [2015] OJ L337/35 (PSD2). 
EU law, the CJEU regards claimants as integration agents who facilitate its enforcement. Accordingly, the EU law principle of effectiveness may require Member States to provide for private law remedies even where a particular EU secondary measure is silent on this issue (and thus falls within the first category of the above classification), including where it explicitly prescribes administrative enforcement mode.

While this line of argument certainly has merit from a top-down perspective on the relationship between EU law and national law on the remedial front, my own view is that in order to better understand this intricate relationship, we also need to examine the legal grammar of EU measures in the field of financial law from a bottom-up perspective. This empirical and theoretical analysis implies the need to consider the actual and potential harmonisation scope of a particular measure in the light of what actually happens with it on the ground - that is in the national legal systems of the Member States and within the framework of the national courts' dialogue with the CJEU through the preliminary reference procedure. How do Member States tend to implement each of the three categories of EU measures identified above - in public law, private law, or both $?^{35}$ In particular, do they tend to provide for private law remedies, including civil liability, where EU measures are silent on this issue? If only administrative sanctions for breach of EU conduct of business rules are envisaged at both EU and national level, are the CJEU and national courts able and willing to equip individuals with private law remedies? Does the principle of effectiveness provide sufficient guidance to national courts in such a case? And does it matter for the position of an aggrieved individual in his or her national legal system, and in terms of the effectiveness of EU law more generally, whether a particular EU measure explicitly includes or excludes private law rights or remedies? These questions in fact boil down to considering the role of the traditional distinction between public and private law in European law today, given the EU law's inherent reliance on national law regarding remedial issues. ${ }^{36}$ Does an increasing entanglement of the public and private spheres and enforcement modes in the process of Europeanisation imply that this orthodox distinction has not played any role whatsoever in the making of EU financial regulation? Or does it mean that this distinction has become wholly obsolete in the context of a post-nation-state European finan-

35 While the conceptual distinction between public and private law has primarily evolved in continental legal systems, it is not entirely unknown to common law countries either. In particular, the conventional assumptions about private law as a distinct conceptual category have been tacitly reflected in the English private common law discourse. See, e.g., Collins (n. 8) at 31.

36 On this in more detail, see O.O. Cherednychenko, 'Rediscovering the Public/ Private Divide in EU Private Law' (2019) ELJ 1. 
cial law laboratory and that it should therefore be simply disregarded by the EU legislature as the irrelevant legacy of the nation-state era? My examination along these lines below suggests that the EU measures in the field of financial law display some signs of the traditional distinction between public and private law and that these measures (or their particular components) can thus also be categorised into public or private law oriented.

The 'public law' grammar is generally manifest in the EU measures belonging to the first category of Tridimas' classification - measures that are silent on private law rights and/or remedies, particularly when they do explicitly provide for administrative enforcement mode. Consider, for instance, MiFID II and its predecessor MiFID I. These directives were drafted from the perspective of ensuring effective supervision of securities markets. To enhance investor protection, they transformed many duties of care and loyalty, typically owed by investment firms towards their clients under national private law, into supervision standards, thus making them part of European financial supervision private law. However, the EU legislator did not explicitly confer civil liability rights on investors in case of their breach. Moreover, while the initial consultation document of the European Commission included the 'principle of civil liability', ${ }^{37}$ the latter ultimately did not make it into the text of MiFID II, in particular as a result of the resistance of the financial industry, coupled with the disagreement among Member States. ${ }^{38}$ At the same time, the directive did strengthen an administrative enforcement toolkit of national financial regulators by specifying the range of administrative sanctions, including pecuniary penalties, which should be employed for certain types of breach and how the determination as to the appropriate sanction and level of sanction should be made. ${ }^{39}$ A clear orientation of MiFID I and MiFID II towards administrative law has led Member States to implement the conduct of business rules contained therein within financial supervision frameworks, leaving the issue of their private law effect in the investment firm-client relationship to national civil courts. ${ }^{40}$ The latter in turn have demonstrated varying degrees of willingness to give such effect in their legal systems. As Marnix Wallinga demonstrates in his chapter in this volume, Dutch and English courts generally tend to consider regulatory conduct of business rules when determining

37 See European Commission, Public Consultation. Review of the Markets in Financial Instruments Directive (MiFID) (MiFID Review) 63, 7.2.6 (liability of firms providing services).

38 Cf. N. Moloney, 'Liability of Asset Managers: A Comment' (2012) 7 CMLJ 414, at 421 .

39 See, in particular, MiFID II, arts 70-72.

40 Cherednychenko (n. 5) at 623. 
the private law standard of care or loyalty in contract or tort. ${ }^{41}$ The German Supreme Court (Bundesgerichtshof $(\mathrm{BGH})$ ), by contrast, is reluctant to do so, denying aggrieved investors the possibility not only to claim damages for breach of the conduct of business rules on the basis of non-contractual liability for breach of a statutory duty, ${ }^{42}$ but also to benefit from the indirect effect (Ausstrahlungswirkung) of such rules on the standard of care in contract. ${ }^{43}$

We should also note that the preliminary reference by the Spanish court in Genil $^{44}$ provided the CJEU with the opportunity to unequivocally clarify its stance on the issue of the relationship between the MiFID I and MiFID II conduct of business rules and national private law. In particular, the national court asked whether the investment firm's failure to carry out the 'appropriateness' and 'suitability' tests required by MiFID I should result in the nullity of the contract between the firm and the investor. However, as Wallinga explains, the Court has not seized this opportunity, merely stating that, in the absence of EU legislation on this point, it is for the internal legal order of each Member State to determine the contractual consequences of non-compliance with the MiFID I conduct of business rules, subject to observance of the principles of equivalence and effectiveness. ${ }^{45}$ Wallinga argues that this dictum of the CJEU does not support the view that MiFID I and MiFID II create individual rights to claim damages through private law rules on civil liability, particularly given the rejection of this principle in the legislative process. Indeed, as Tridimas also points out, the CJEU did not recognise an implied right of action in this case, even though the conduct of business rules at issue did aim to protect investors and were sufficiently precise and detailed. In his view, a restrictive answer by the CJEU in Genil could in part be explained by a somewhat narrow formulation of the national court's question. Yet it may also be a sign of the Court's reluctance to adopt a uniform approach towards such a sensitive issue as the relationship between EU investor protection regulation and traditional private law, given the clear focus of MiFID I and II on public supervision and

${ }^{41}$ For the Netherlands, see, e.g., HR 5 June 2009, ECLI:NL:HR:2009:BH2815 (Dexia v. De Treek); HR 5 June 2009, ECLI:NL:HR:2009:BH2811 (Levob Bank v. Bolle); HR 5 June 2009, ECLI:NL:HR:2009:BH2822 (Stichting GeSp v. Aegon Bank). For England and Wales, see, e.g., Gorham \& Others v. British Telecommunications Limited plc [2000] EWCA Civ 234.

42 See, e.g., BGH 19 February 2008, XI ZR 170/07, NJW 2008, 1734; BGH 22 June 2010, VI ZR 212/09, NJW 2010, 3651.

43 See, e.g., BGH 3 June 2014, XI ZR 147/12, no. 35, NJW 2014, 2947; BGH 17 September 2013, XI ZR 332/12, WM 2013, 1983; BGH 27 September 2011, XI ZR 178/10, NJW-RR 2012, 43.

44 Case C-604/11, Genil v. Bankinter, ECLI:EU:C:2013:344.

45 Ibid., paras 57-58. Cf., e.g., S. Grundmann, 'The Bankinter Case on MiFID Regulation and Contract Law’ (2013) 9 ERCL 267, at 275. 
enforcement. In any case, in the absence of legislative guidance on this issue at EU level, in some Member States aggrieved retail investors may not be able to rely on the national public law standards of financial supervision implementing the MiFID II conduct of business rules before civil courts. Yet these regulatory rules may provide for a higher level of investor protection than that afforded under national private law. Even though the use of the 'public law' grammar by the EU legislator in itself does not preclude national courts from giving effect to them within traditional private law, whether and to what extent courts actually do so may vary considerably across the EU.

Another, even more striking, example of the use of the 'public law' grammar in EU financial regulation is the European Market Infrastructure Regulation (EMIR) ${ }^{46}$ - tellingly, an EU measure which does not entirely fall within the first category of Tridimas' classification. This regulation was adopted in the aftermath of the financial crisis with a view to increasing transparency in the over-the-counter (OTC) derivatives markets, mitigating credit risk and reducing operational risks. In particular, Title II of EMIR lays down clearing, reporting, and risk mitigation obligations for counterparties to OTC derivative contracts and central counterparties (CCPs). In terms of enforcement, this Title makes it clear that Member States should have financial supervisory authorities in place and that such authorities should be entitled to impose penalties, including at least administrative fines, and be obliged to disclose every penalty that has been imposed. ${ }^{47}$ Further, it expressly states that the infringement of the obligations at issue shall not affect the validity of an OTC derivative contract and shall not give rise to any right to compensation from a party to that contract. ${ }^{48}$ Title II of EMIR thus appears to fall into the second category of Tridimas' classification - EU measures that make a general reference to national private law remedies. Yet, this regulatory regime stands in sharp contrast with that of the Prospectus Regulation - another EU measure within this category mentioned above - in that it does not ensure the application of national private law remedies in case of breach of EU law but profoundly restricts it, focussing on public enforcement means instead. As Federico Della Negra observes in his contribution to this volume, EMIR does not specify the rationale for the limitation of private law rights of action for breach of regulatory duties under Title II. In his view, this restriction can be explained by the need to ensure the efficiency of the OTC derivatives markets and to mitigate the systemic risk that may arise from private litigation. $\mathrm{He}$

46 Regulation (EU) No 648/2012 of the European Parliament and of the Council of 4 July 2012 on OTC derivatives, central counterparties and trade repositories [2012] OJ L201/1 (EMIR).

47 EMIR, art. 12(1), (2).

48 Ibid., art. 12(3). 
doubts, however, whether reducing civil litigation regarding OTC derivatives will really prove beneficial for financial stability. After all, adjudication by the courts may increase the transparency of the OTC derivatives markets by generating publicly available information about derivatives products and the transactions deploying them, as well as the nature and scope of such markets. In any case, this example shows that an EU intervention in the domain of private law remedies may not necessarily serve to strengthen the position of those affected by breach of EU regulatory standards, but rather to weaken it in the pursuit of some overriding public interest, which, according to the EU legislator, is best served by public law tools.

In contrast, the 'private law' grammar is particularly evident in the EU measures belonging to the third category of Tridimas' classification - measures that expressly provide for European private law rights and remedies. While the degree of legislative harmonisation varies considerably across such measures, they all ensure the existence of (at least some) private law rights or remedies at EU level. For instance, even though the provision on civil liability in the CRA Regulation relies heavily on national law, as Chiara Picciau points out in her contribution to this volume, its adoption has considerably improved the chances of European investors to hold credit rating agencies liable. Despite the fact that these agencies could be held liable even before then, in the absence of specific national rules on their civil liability, coupled with the lack of a contractual relationship between the agencies and the investors, this prospect remained no more than a theoretical possibility. In her view, the main innovation of the civil liability rule of the CRA Regulation is that it dispels any doubt as to whether the agencies may be held accountable to the investing public at large in the EU through private law.

The most striking example of the 'private law' grammar in EU financial regulation, however, is PSD2. It seeks to foster competition and innovation in the payments sector while at the same ensuring a high level of consumer protection. For these purposes, the EU legislator has chosen a combination of public and private law instruments. The former govern authorisation and supervision of payment service providers, and, in particular, require banks to allow non-bank, typically 'fintech', payment service providers (referred to as payment initiation service providers and account information service providers) to access banks' payment systems and client databases ${ }^{49}$ The latter concern transparency and rights and obligations in relation to the provision and use of payment services..$^{50}$ The private law component of PSD2 is especially strong compared to other measures in the field of financial law. In particular,

49 PSD2, titles I and II.

50 Ibid., titles III and IV. 
this directive not only contains detailed information requirements for payment service providers, but also places the burden of proof in relation to such requirements with the providers, thus acknowledging the procedural difficulties faced by consumers in enforcing them. ${ }^{51}$ In addition, PSD2 specifies not only contractual obligations of payment service providers, ${ }^{52}$ but also those of payment service users. The latter include the duty to use the payment instrument in accordance with applicable contract terms and the duty to notify the provider without undue delay on becoming aware of the loss, theft, misappropriation, or unauthorised use of the payment instrument. ${ }^{53}$ Even more tellingly, as noted above, PSD2 also provides for detailed liability rules, governing the allocation of losses resulting from fraud, forgery, and error between payment service providers and users. ${ }^{54}$ As Agnieszka Janczuk-Gorywoda argues in her chapter in this volume, these rules, which lie at the heart of payments law, are designed not only to do justice between these private parties, but also to serve the multiple policy goals pursued by PSD2, allocating the lion's share of liability for losses to the providers. For instance, as a general rule, the providers are liable for all losses related to unauthorised payment transactions, ${ }^{55}$ which not only serves to protect consumers but also contributes to the safety of payment systems and market integration.

These provisions of PSD2 clearly show that, even though this directive requires Member States to ensure administrative enforcement of implementing rules, ${ }^{56}$ it is concerned with ensuring the balance between the interests of payment service providers and users. The impact of PSD2 on national private law is therefore undisputed. This does not necessarily mean that all substantive PSD2 rules have been integrated into private law at national level. The way in which PSD2 has been implemented in the Netherlands, for instance, illustrates this point. While the directive's private law component has for the most part been transposed into the Dutch Civil Code, ${ }^{57}$ the detailed information requirements have been translated into substantive financial supervision standards of a public law nature. ${ }^{58}$ By making cross-references to these standards in the Civil Code, ${ }^{59}$ however, the Dutch legislator has ensured that the information

\footnotetext{
Ibid., art. 41.

Ibid., title IV.

Ibid., art. 69.

Ibid., arts 20, 73, 74, 88-93.

Ibid., art. 73.

Ibid., art. 100.

Dutch Civil Code (Burgerlijk Wetboek $(B W)$ ), book 7, title 7B.

Financial Supervision Act (Wet op het financieel toezicht (Wft)) 2006, art. 4:22.

See also Business Conduct Supervision (Financial Enterprises) Decree 2006 (Besluit Gedragstoezicht financiële ondernemingen Wft (BGfo)), arts 59b-59g.

59 See, e.g., Dutch Civil Code, arts 516, 517, 526.
} 
rules of PSD2 are not only relevant from a supervisory perspective, but that they also govern the private law relationship between payment service providers and users and can be enforced through private law. ${ }^{60} \mathrm{~A}$ marked orientation of the important parts of PSD2 towards private law appears to have prompted the Dutch legislator to adopt this solution. ${ }^{61}$

Furthermore, private law elements can also be distinguished in some EU measures belonging to the first and second category of Tridimas' classification. While the Consumer Credit Directive and Mortgage Credit Directive, for instance, are silent on private law remedies for violation of harmonised obligations of creditors and credit intermediaries (and thus fit into the first category), both directives do expressly confer certain European private law rights on consumers, such as the right of withdrawal from a credit agreement ${ }^{62}$ and the right to early repayment. ${ }^{63}$ Insofar as these rights are concerned, therefore, there is no question that they give rise to private law consequences. Similarly, a modest private law element is also present in the Prospectus Regulation. Even though, in harmonising administrative sanctions for infringement of its standards, ${ }^{64}$ this EU measure is primarily oriented towards public law, as noted above, it also explicitly requires Member States to apply their national laws on civil liability (and thus fits into the second category). The provision at issue does not harmonise rules on civil liability in case of breach of the EU prospectus rules, but it does clearly preclude Member States from excluding this private law remedy in such a case.

As this bottom-up analysis of the EU financial regulation shows, the public/ private divide is manifest therein in the varying extent to which various EU measures engage with private law relationships when pursuing similar policy objectives. Some EU measures, such as MiFID II or EMIR, generally rely on public law instruments, focussing on the relationship between regulators and regulatees and sometimes even expressly excluding recourse to private law remedies, notably civil liability. In contrast, other EU measures, such as PSD2, combine public and private law tools, explicitly conferring European private law rights and/or remedies on individuals. Moreover, the legal grammar of

60 Conversely, those provisions of the PSD2 that have been implemented into the Dutch Civil Code can be enforced through administrative law means. This outcome has been achieved through the inclusion of a special provision - Article 4:25d - into the Financial Supervision Act 2006, according to which a payment service provider must comply with Title $7 \mathrm{~B}$ of Book 7 of the Dutch Civil Code.

${ }_{61}$ Implementatiewet herziene richtlijn betaaldiensten: Memorie van Toelichting, Kamerstukken 34813, n. 3, 14-15.

62 Consumer Credit Directive, art. 14; Mortgage Credit Directive, art. 14(6).

63 Consumer Credit Directive, art. 16; Mortgage Credit Directive, art. 25.

64 Prospectus Regulation, chapters VII and VIII, in particular art. 38. 
a particular EU measure (or part of it) - which can thus be 'public' or 'private' - does matter in practice in terms of individual rights and remedies at national level and the CJEU's likely activism in this context. Member States are clearly obliged to provide for such rights and remedies within their national legal orders where a given EU measure is concerned, inter alia, with interpersonal justice. Yet, they have much more room for manoeuvre where this is not the case. The difference between the 'public' and 'private law' grammar in terms of individual rights and remedies may be reduced to some degree by the CJEU. Indeed, as the top-down analysis by Tridimas suggests, to the extent that a particular public law-oriented EU measure also aims to protect the interests of private parties, the CJEU may interpret it in the light of the EU doctrine of implied rights and the principle of effectiveness so as to enhance its potential to provide for individual redress. At the same time, the Court's ability and willingness to do so in case of 'public law' grammar is not self-evident. ${ }^{65}$ The CJEU's ability to imply individual rights of action in 'public law'-coloured EU measures can be limited by their wording, which, as exemplified by EMIR, may even explicitly exclude certain private law remedies. Further, as its case law regarding the predecessor of MiFID II demonstrates, the Court may be reluctant to 'insert' private law remedies in such measures.

While the bottom-up perspective on the relationship between EU financial regulation and national law regarding remedial issues thus places accents differently than the top-down perspective does, both kinds of analysis reveal a pervasive lack of a coordinated approach at EU level to financial regulation and civil liability across various sectors of financial services and activities. It is especially striking that the major financial consumer/retail investor protection measures in the field of payments, credit, and investment have all adopted different approaches to this issue. As noted already, PSD2 integrated a robust private law component within its ambit, providing for European private law rights and remedies. In contrast, no such rights and remedies were included in the public law-oriented MiFID II, which remained silent on this issue while enhancing administrative enforcement. And only a few private law rights were inserted into the Consumer Credit Directive and Mortgage Credit Directive, with neither directive providing for private law remedies or administrative sanctions. Moreover, in the securities field alone, as Della Negra shows in his chapter, there is a variety of enforcement regimes in both retail and wholesale markets, reflecting a fragmented and 'silo-based' regulatory approach to

65 My earlier research suggests that the CJEU has mainly adopted an activist approach in cases involving the private law-oriented EU measures, such as the Unfair Contract Terms Directive and the Product Liability Directive, strengthening the link between individual rights, private law remedies, and civil procedures. See Cherednychenko (n. 36). 
marketing, sale, and distribution of financial instruments in the EU. Different regimes apply to issuers, intermediaries, and gatekeepers, ranging from the explicit rejection of civil liability (e.g., EMIR) to the introduction of a European civil liability regime (e.g., CRA Regulation), with a varying degree of reliance on national law.

Overall, diversity in enforcement regimes and interpersonal justice deficit across the EU harmonisation measure in the field of financial law is not the result of a systematic analysis of the relative merits of the public and private enforcement models in terms of their appropriateness for achieving particular policy objectives in specific contexts. In particular, as Michael Faure and Franziska Weber argue in their contribution to this volume, the choices made by the EU legislator cannot be entirely explained in terms of the economic rationale. According to it, a well-designed enforcement system can induce compliance ex ante if the actors involved have appropriate incentives to act. Private enforcement by holding financial firms liable can function in this way, particularly where individual losses are large, victims can easily obtain information about the infringement and/or the wrongdoer, and access to justice is easy. Moreover, the private enforcement model is preferable to the public enforcement one given its lower costs. A more costly public enforcement should therefore play a secondary role and only be used where private enforcement may not prove to be a sufficient deterrent. However, the analysis of the EU enforcement architecture for the financial sector from this deterrence-oriented law and economics perspective points to a certain mismatch between the two. In some areas, such as payment services, EU financial regulation is generally in line with the law and economics model in that it relies considerably on private enforcement. But in other areas, such as retail investment services, this is not the case, with MiFID I and MiFID II being notably silent on civil liability.

Apart from the overall regulatory bias of the EU integration paradigm, the public or private law orientation of EU measures in the field of financial law appears to be primarily dictated by the path dependency of harmonisation in a given area (notably pre-existence of the national or EU legal framework of a particular type, such as in the case of PSD2 and MiFID II) and/or the political constraints surrounding the EU law-making process (notably resistance of the industry and/or Member States to the harmonisation of civil liability, as exemplified by the legislative history of MiFID II). Interestingly, the historical dynamics of the EU harmonisation of financial law do not appear to be the decisive factor in this context, as demonstrated by the use of different grammar options in PSD2 (both public and private law) and MiFID II (public law), both 
of which were adopted in the third harmonisation phase when full harmonisation and 'agencification' were on the rise. ${ }^{66}$

\subsection{Cross-actor Coordination?}

So far we have only considered in detail whether there is a coordinated approach to private law remedies, particularly civil liability, for breach of regulatory standards across the different sectors of financial services and activities harmonised by EU law. It has been generally recognised, however, that private enforcement alone is not sufficient to ensure the effectiveness of such standards in practice. It is the combination of public and private enforcement that is needed for achieving desired results. Today European financial law is enforced through public law, notably administrative law, and private law means. In theory, these two enforcement modes can be alternative systems, but in practice they coexist. ${ }^{67}$ Moreover, the EU has promoted a tripartite approach to enforcement in this area, with courts (including both administrative and civil courts), ADR bodies and financial regulators standing side by side in ensuring deterrence and compensation. ${ }^{68}$ This coexistence of different actors in the enforcement domain points to the need for coordination between them.

It is widely acknowledged in the law and economics literature that public and private enforcement should complement each other so as to avoid any conflict or overlap between them. ${ }^{69}$ This idea of complementarity implies a strict separation between a regulatory, deterrence-oriented, function of administrative enforcement pursued by public authorities, on the one hand, and a compensatory function of private enforcement exercised by civil courts and ADR entities, on the other. Yet, designing a perfect complementarity between public and private enforcement in a particular field is not an easy task. ${ }^{70}$ Reinforcing one enforcement mode in fact increases the risk of adverse side-effects on the other mode. The complementarity between public and private enforcement, however, can also be understood in another, less ambitious sense - that is, as a state where there is at least some degree of cooperation between public and

\footnotetext{
${ }^{66}$ On the historical dynamics of European integration in European private law, see Micklitz (n. 4) 164.

${ }_{67}$ Cf. Cafaggi \& Iamiceli (n. 2) at 610.

68 A similar trend can be observed in EU labour and consumer law. See Micklitz (n. 4) 335 .

69 See, e.g., S. Shavell, Foundations of Economic Analysis of Law (Belknap 2004) 589; C.D. Kolstad et al., 'Ex Post Liability for Harm vs. Ex Ante Safety Regulation: Substitutes or Complements?' (1990) 80 AER 888.

70 F. Weber \& M. Faure, 'The Interplay between Public and Private Enforcement in European Private Law: Law \& Economics Perspective’ (2015) 23 ERPL 525.
} 
private enforcers with a view to ensuring coordination between their activities in the regulatory and compensatory domains. ${ }^{71}$

Such cross-actor coordination is not an end in itself. As will be shown below, it is needed to maximise the effectiveness of private enforcement, notably through civil liability rules - and that of the combined public/private enforcement mechanism as a whole - and dissuade potential wrongdoers from committing infringements, while at the same time preventing over-deterrence, in accordance with the requirements of effectiveness, proportionality, and dissuasiveness. It is arguable that these principles are relevant not only within a particular enforcement mechanism (administrative, criminal, or private), but also across different enforcement mechanisms, supporting the need for cross-actor coordination in a particular area. ${ }^{72}$ It is therefore also necessary to investigate whether there is such coordination in the enforcement of European financial law. In particular, are the finding of an infringement by one enforcer (e.g., a financial regulator) or the evidence available to it relevant in proceedings within other enforcement mechanisms (e.g., before a civil court or an ADR body)? Are the sanctions (e.g., an administrative fine) or remedies (e.g., liability for damages) imposed by a previous enforcer being considered in subsequent proceedings (administrative or judicial) when determining appropriate sanctions or remedies? Do various enforcers at least exchange information concerning infringements with each other? Has cross-actor coordination in enforcement matters been promoted at EU level? Or do the Member States tend to develop it without being prompted by the EU?

The chapters in this collection show that a coordinated approach to the public and private enforcement of financial regulation at EU level is generally lacking. A modest degree of coordination has so far been envisaged by the EU legislator only between administrative agencies responsible for consumer protection, including those in financial services, and consumer ADR bodies. The Consumer ADR Directive obliges Member States to ensure cooperation between these actors that would include (a) mutual exchange of information on practices about which consumers have repeatedly lodged complaints, and (b) the provision of technical assessment and information by administrative agencies to ADR bodies where these are necessary for the handling of individual disputes and are already available. ${ }^{73}$ In addition, this directive also specifies in detail what type of information should be communicated by ADR entities to administrative agencies every two years. This information should

Cherednychenko (n. 5) at 641.

72 With respect to the enforcement of consumer law, cf. Cafaggi \& Iamiceli (n. 2) at 610 .

73 Consumer ADR Directive, art. 17(1), (2). 
include, for example, data on the number of disputes received and the types of complaints to which they relate; the rate of compliance, if known, with the outcomes of the ADR procedures; and any systematic or significant problems that occur frequently and lead to disputes between consumers and traders. ${ }^{74}$ ADR entities may also accompany the information about consumer problems with recommendations as to how they could be avoided or resolved in the future. ${ }^{75}$ Such information exchange can certainly assist financial regulators in ensuring effective supervision of the retail markets and ADR bodies in providing consumer redress. Yet, there must be doubt about whether this is sufficient to ensure effective cross-actor coordination in the field of financial law, and thus the effective, proportionate, and dissuasive enforcement of EU financial regulation through public and private law means. Most importantly, there is no legislative or judicial coordination at EU level of various enforcement actions in this area in terms of the sequentiality of such actions (whereby one enforcer must stay the proceedings until the other has issued a final decision) and/or the legal status of the final decision of a previous enforcer (which can be binding on subsequent enforcers). At least three points deserve closer scrutiny in this connection.

First, in the field of financial law, civil courts are not legally bound by decisions of administrative agencies establishing a violation of a particular regulatory standard. Such coordination has been envisaged by the EU legislator, for instance, in the field of competition law, which is enforced by the European Commission, national competition authorities, and national courts (including civil courts). According to Council Regulation (EC) No $1 / 2003,{ }^{76}$ when a national court rules on a matter which is already the subject of a Commission decision, its decision cannot run counter to that of the Commission; courts must also avoid giving decisions which would conflict with a decision contemplated by the Commission in proceedings it has initiated and, if necessary, may stay judicial proceedings. ${ }^{77}$ Moreover, the Antitrust Damages Directive,$^{78}$ designed to promote private enforcement, and thus strengthen

74 Ibid., art. 19(3).

75 Ibid., art. 19(3)(e).

76 Council Regulation (EC) No 1/2003 of 16 December 2002 on the implementation of the rules on competition laid down in Articles 81 and 82 of the Treaty [2003] OJ L1/1 (Council Regulation (EC) No 1/2003).

77 Ibid., art. 16(1).

78 Directive 2014/104/EU of the European Parliament and of the Council of 26 November 2014 on certain rules governing actions for damages under national law for infringements of the competition law provisions of the Member States and of the European Union [2014] OJ L349/1 (Antitrust Damages Directive). 
the enforcement of EU competition law more generally, ${ }^{79}$ requires Member States to "ensure that an infringement of competition law found by a final decision of a national competition authority or by a review court is deemed to be irrefutably established for the purposes of an action for damages brought before their national courts under Articles 101 or 102 TFEU or under national competition law' ${ }^{80}$ Accordingly, in deciding whether an undertaking is liable for breach of EU competition law to consumers, other undertakings, or public authorities, civil courts are legally bound by the final decisions of the European Commission, national competition authorities, and reviewing administrative courts. However, in the absence of any such coordination designed to facilitate private enforcement in the field of financial law, weaker financial market participants may not be able to effectively exercise their civil liability rights, and hence complement public enforcement.

The enforcement design of the CRA Regulation is a case in point. This EU measure combines the administrative enforcement by ESMA with the private enforcement by investors and issuers. The latter is supposed to complement the former not only in ensuring compensation for aggrieved individuals, but also in effectively deterring credit rating agencies from committing the infringements listed in Annex III to the regulation. ${ }^{81}$ Where these infringements have been committed intentionally or with gross negligence, they can lead to the imposition of administrative sanctions, including public notices and fines, and civil liability for damages. ${ }^{82}$ Yet, as Chiara Picciau and Francesco de Pascalis demonstrate in their contributions to this volume, the public and private enforcement envisaged by the CRA Regulation are not interconnected, which makes it difficult for investors to exercise their EU right to compensation based on the civil liability rule included therein. One of the major hurdles investors face in practice is presenting 'accurate and detailed information' to prove that the credit rating agency has committed one of the infringements listed in Annex III. ${ }^{83}$ That this is not an easy task, given the information asymmetries between credit rating agencies and investors, was acknowledged by the European Commission in its initial proposal for the CRA

79 See, e.g., J. Drexl, 'The Interaction between Private and Public Enforcement in European Competition Law' in H.-W. Micklitz \& A. Wechsler (eds), The Transformation of Enforcement: European Economic Law in a Global Perspective (Hart 2016) 136.

80 Antitrust Damages Directive, art. 9(1).

81 European Commission, Impact assessment accompanying Proposal for a Regulation amending Regulation (EC) No 1060/2009 on credit rating agencies, SEC(2011) 1354 final, 47.

82 CRA Regulation, arts 24(1), 35a(1) and 36a(1).

83 Ibid., art. 35a(2). 
Regulation. ${ }^{84}$ It contained a provision stating that where an investor establishes facts from which it may be inferred that a credit rating agency has committed an infringement, it is for the agency to prove the contrary. In the absence of such a reversal of the burden of proof in the final text, the evidential difficulty for investors could be addressed by allowing them to rely in civil proceedings on ESMA's finding of an infringement. However, in contrast to the Antitrust Damages Directive, the CRA Regulation does not contain any provision to this effect, merely stating that the investors' right of redress under this regulation does not prevent ESMA from fully exercising its powers to impose fines. ${ }^{85} \mathrm{As}$ a result, as de Pascalis points out, the public enforcement mechanism of the CRA Regulation currently works without its 'natural' complement - that is, the private enforcement mechanism centred around the potential civil liability of credit rating agencies.

In the absence of EU rules on this matter, some Member States have developed some degree of coordination between financial regulators and civil courts with a view to enhancing private enforcement. An example of such coordination can be found in French law. Following the conventional division of labour between public and private enforcement, the French financial watchdog, Autorité des marchés financiers (AMF), is typically not involved in awarding compensation or otherwise resolving problems arising out of private law relationships between financial institutions and their (potential) clients. ${ }^{86}$ If the latter, therefore, have suffered losses, they will need to turn to civil courts to obtain compensation. At the same time, French law allows AMF to transmit the files of its administrative investigation to the civil court at the request of the judge hearing a civil lawsuit if these documents are relevant for resolving it. ${ }^{87}$ Accordingly, aggrieved litigants may benefit from the information obtained in the course of public supervision.

Another example of the emerging cooperation between financial regulators and civil courts is provided by German law. The financial supervision legislation - the Securities Trading Act (Wertpapierhandelsgesetz (WpHG)) - imposes an obligation on investment firms and credit institutions to maintain written minutes of all investment advice provided to retail clients. ${ }^{88}$

84 European Commission, Proposal for a Regulation of the European Parliament and of the Council amending Regulation (EC) No 1060/2009 on credit rating agencies, $\operatorname{COM}(2011) 0747$ final, art. 35a(4).

85 CRA Regulation, art. 35a(6).

86 Y. Svetiev Y \& A. Ottow, 'Financial Supervision in the Interstices between Private and Public Law' (2014) 10 ERCL 496-544, at 527.

87 Loi n $^{\circ}$ 2014-344 du 17 mars 2014 relative à law consummation, art. L 621-12-1. See also Svetiev \& Ottow (n. 86) at 527.

88 WpHG, s. 34 (2a). 
Interestingly, this provision is not only intended to assist the German financial watchdog, Bundesanstalt für Finanzdienstleistungsaufsicht (Bafin), in performing its supervisory functions. In fact, its primary aim is to strengthen the clients' rights in case of a dispute with a financial institution concerning the quality of investment advice, and thus to facilitate civil lawsuits by aggrieved investors. ${ }^{89}$ In this way, financial supervision law addresses the procedural difficulties faced by retail investors in proving that the advice they have received was wrongful. Moreover, the Bafin has made considerable efforts to improve the quality of investment advice minutes. ${ }^{90}$

Second, the sanctions or remedies for violation of financial law imposed within one enforcement mechanism are generally irrelevant within other such mechanisms. In the absence of any coordination between financial regulators and civil courts in this domain, a combination of public and private enforcement systems becomes particularly contentious where both public and private law tools serve to deter infringements. After all, the concurrent application of such instruments may result in disproportionate sanctioning. As already noted, a deterrent function of private law remedies has been acknowledged by the CJEU. At the same time, when reviewing the conformity of such national remedies for breach of consumer credit regulations with EU law, the CJEU does not take into account whether administrative sanctions are also available. ${ }^{91}$ In his chapter in this book, Reinhard Steennot examines this case law. He observes that the CJEU has made it clear that deterrent private law remedies exceeding the amount of the losses suffered by consumers are generally allowed. Yet, the Court has not shed much light on the issue of whether national laws must always provide for such remedies in order to meet the requirements of effectiveness and dissuasiveness. Using Belgian law as an example, Steennot shows that an affirmative answer to this question can be problematic. Private law remedies in this legal system are not only designed to compensate consumers for the damage suffered, but also to deter creditors and credit intermediaries from violating the law. For instance, if the creditor has charged the consumer the annual percentage rate in excess of the maximum rate that is allowed by consumer credit regulations, the creditor is not entitled to any interest or costs, which effectively means that the consumer obtains the credit for free. In addition, infringements of consumer credit regulations can

89 See M. Michel \& C.-J. Yoo/BaFin, 'Investment Advice Minutes and the Employee and Complaints Register in Supervisory Practice', http:/www.bafin.de/SharedDocs/ Veroeffentlichungen/EN/Fachartikel/2013/fa_bj_2013_07_beratungsprotokoll _aufsichtspraxis_en.html?nn=3698804, accessed 30 April $20 \overline{2} 0$.

90 Svetiev \& Ottow (n. 86) at 536.

91 See, e.g., Case C-565/12, Fesih Kalhan, ECLI:EU:C:2014:190; Case C-42/15, Home Credit Slovakia, ECLI:EU:C:2016:842. 
also be sanctioned by administrative law. When determining private law remedies, Belgian civil courts may not consider the administrative fines already imposed on the wrongdoers. As a result, a combination of punitive private law remedies with severe administrative sanctions may be disproportionate and therefore contrary to EU law. In light of this, Steennot advances the view that the answer to the question of whether deterrent private law remedies are required under EU law should depend on the availability and the actual use of public enforcement tools. It may only be appropriate to introduce deterrent private law remedies where effective administrative or penal sanctions do not exist. In this case, consumers should be sufficiently incentivised to make use of private law remedies to enforce consumer credit law.

However, in a more recent judgment in OPR-Finance, ${ }^{92}$ the CJEU has expressed its reluctance to establish a link between private law remedies and administrative sanctions for breach of the Consumer Credit Directive. The case revolved around the provision of Czech law that penalised the creditor's violation of a duty to assess the consumer's creditworthiness ${ }^{93}$ with the nullity of the credit agreement, coupled with the loss of the entitlement to the agreed interest and costs. Yet, to benefit from this remedy, the consumer was required to raise the objection of nullity within a limitation period of three years from the conclusion of the agreement. While the Court held that the private law remedy at issue was proportionate and 'genuinely dissuasive', ${ }^{94}$ it found the condition for its exercise to be contrary to the principle of effectiveness. ${ }^{95}$ According to the CJEU, national courts are obliged to examine of their own motion whether the creditor has complied with its duty to assess the consumer's creditworthiness and to draw the consequences of its breach under national law in line with the requirements of effectiveness, proportionality, and dissuasiveness. ${ }^{96}$ Importantly, the CJEU dismissed the argument raised by the Czech government that the infringement of this duty is subject to an administrative penalty in the form of a fine of CZK 20 million (approximately EUR 783,000). The Court noted that the Czech financial regulator has never notified the European Commission of any decision imposing such a fine. ${ }^{97}$ Following the opinion of Advocate General Kokott, ${ }^{98}$ it also observed that administrative penalties on their own are not capable of ensuring sufficiently effective consumer protec-

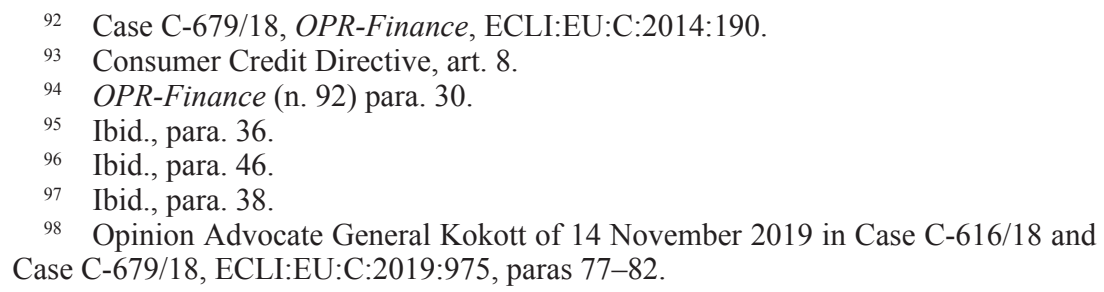


tion against over-indebtedness and insolvency sought by the Consumer Credit Directive, in so far as they have no effect on the situation of an individual consumer. ${ }^{99}$ The Court concluded that in any event, where the national legislature has, in addition to an administrative penalty, provided for a civil penalty for breach of this directive from which the consumer may benefit, that civil penalty must be implemented in compliance with the principle of effectiveness, given the particular importance afforded by the directive to consumer protection. ${ }^{100}$ Thus, while emphasising the importance of dissuasive private law remedies in protecting consumers, the CJEU does not appear to acknowledge the need for assessing such remedies in the context of the combined public and private enforcement of EU financial regulation.

Third, there is hardly any coordination between financial regulators, on the one hand, and civil courts and ADR bodies, on the other, in the case of hybrid enforcement whereby an administrative agency may pursue not only deterrence, but also compensation of mass damage. ${ }^{101}$ The EU legislator appears to encourage the involvement of financial regulators in providing collective consumer redress. For instance, the MiFID II provisions on supervisory powers require Member States to provide for mechanisms that would ensure compensation or other remedial action for any financial loss suffered as a result of an infringement of MiFID II or MiFIR. ${ }^{102}$ Administrative agencies also figure prominently in the proposal of the European Commission for a directive on representative actions for the protection of the collective interests of consumers, ${ }^{103}$ which, as noted above, covers infringements of the EU measures in the field of consumer finance. ${ }^{104}$ According to the proposal, both judicial and administrative procedures may effectively and efficiently serve the protection of the collective consumer interests, and it is therefore up to the Member States to decide whether the representative action by qualified entities can be brought in judicial or administrative proceedings, or in both. ${ }^{105}$ Importantly, such action before an administrative authority may seek not only an injunction, but also a redress order obliging the trader to provide compensation or, alternatively, a declaratory decision regarding the liability of the trader towards aggrieved

\footnotetext{
99 OPR-Finance (n. 92) para. 38.

100 Ibid., para. 39.

101 See also Cherednychenko (n. 5) at 643.

102 MiFID II, art. 69(2). See also the chapters by Federico Della Negra and Marnix W. Wallinga in this volume.

103 European Commission, Proposal for a Directive of the European Parliament and of the Council on representative actions for the protection of the collective interests of consumers, COM(2018) 184 final.

104 Ibid., Annex I.

105 Ibid., recital 12.
} 
consumers. ${ }^{106}$ In addition, the proposal also requires Member States to equip courts or administrative authorities with the powers to initiate and scrutinise settlements between the parties to the representative actions on redress to be provided for the consumers concerned. ${ }^{107}$ However, neither MiFID II nor the Commission proposal on representative actions addresses the issue of coordination between administrative authorities, courts, and ADR bodies, which can all be potentially involved in the provision of collective redress to retail investors/consumers. This raises serious concerns not only about the effectiveness of the proposed hybrid enforcement mechanisms, but also about legal certainty.

In this context, the UK's experience with hybrid enforcement in the event of widespread or regular failure by financial firms to comply with regulatory standards offers valuable insights. In such a case, the UK's financial watchdog, the Financial Conduct Authority (FCA), may make a consumer redress scheme. ${ }^{108}$ Under this scheme, a financial firm can be required to investigate whether it has failed to comply with the law, to determine whether the failure has caused or may cause loss to consumers, to determine what the redress should be, and to make the redress to the consumers. ${ }^{109}$ Since 2010, compensation has been paid in a series of cases, as a result of either agreements between the FCA and financial firms or the use of the formal powers. ${ }^{110}$ Importantly, the FCA's powers with respect to a consumer redress scheme do not stand alone but are accompanied by a mechanism that ensures coordination of the financial regulator's activities with that of courts and the Financial Ombudsman Service (FOS). In particular, the FCA can only make such a scheme where a court would award redress to consumers. ${ }^{111}$ As the FCA Handbook further clarifies, 'the only failures a consumer redress scheme can address are those that a court or tribunal would find to have been failures at the time the activities were carried on'. ${ }^{12}$ The FCA's powers are thus limited to the extent that the regulator cannot rely on its own subjective assessment of the reasonableness of the financial firm's actions, but should follow the law as interpreted and applied by courts. When the meaning of the law is unclear, the FCA has two options. It may either decide not to develop a scheme at all, considering the other ways in which consumers can seek redress (including through the courts), or it may

\footnotetext{
106 Ibid., arts 5-6.

107 Ibid., art. 8.

108 Financial Services and Markets Act (FSMA) 2000, s. 404.

109 FSMA 2000, s. 404(5)-(7).

110 See Hodges \& Creutzfeldt (n. 6) at 122.

111 FSMA 2000, s. 404(1)(b).

112 Financial Conduct Authority Handbook, s. CONRED 1.3.10. See also s. CONRED 1.3.16.
} 
take steps to clarify the law. ${ }^{113}$ The latter can be done by seeking an opinion from a Queens Counsel or a court declaration. ${ }^{114}$ Further, where a consumer makes a complaint to the FOS in relation to an act or omission of a firm that is covered by a consumer redress scheme, the Ombudsman is required to determine the complaint by reference to what, in its opinion, the determination under the consumer redress scheme should be or should have been (and thus not to what is fair and reasonable). ${ }^{115}$ In effect, this rule requires the FOS to act as an extended arm of the FCA, applying the solution mandated by the regulator (in accordance with the law as interpreted and applied by the judiciary) and deciding whether the firm has acted accordingly.

\section{TOWARDS A MORE COORDINATED APPROACH BETWEEN EU FINANCIAL REGULATION AND CIVIL LIABILITY}

The above discussion reveals a general lack of a coordinated approach to financial regulation and civil liability at EU level. While the national procedural autonomy of the Member States in the field of financial law has been profoundly limited by EU law, the enforcement landscape in this area remains highly fragmented. Private law remedies, notably civil liability, have been harmonised to a varying degree across different sectors of financial services and activities without a solid, scientifically grounded, rationale for each legislative solution. No such rationale can explain, for example, why financial consumers enjoy an extensive set of European private law rights and remedies when using a payment account, but not when investing their savings. After all, in both cases governed, respectively, by PSD2 and MiFID II, the civil liability of financial firms in case of breach of their regulatory duties under EU law may not only ensure compensation for aggrieved individuals, but also deter the firms from infringing such duties in the first place. Furthermore, hardly any significant coordination has been envisaged among the different actors involved in public and private enforcement, with courts, ADR bodies, and financial regulators largely operating independently of each other. Without such coordination, for instance, investors are unlikely to be able to exercise their civil liability rights under the CRA Regulation, while creditors and other financial service providers may become subject to disproportionate penalties. All in all, the current patchwork of rules governing the enforcement of EU

113 Ibid., s. CONRED 1.3.11.

114 Ibid., ss CONRED 1.3.12-1.3.13.

115 FSMA 2000, s. 404B(4). See also Financial Conduct Authority Handbook, ss 1.6.1-1.6.24. 
financial regulation raises serious concerns not only in terms of interpersonal justice, but also in terms of its overall coherence and effectiveness. Against this backdrop, we should consider finally in this introduction how a more coordinated approach to EU financial regulation and civil liability can be developed, particularly given the significant implications of the solutions adopted at EU level for the availability of private law remedies at national level and the intricacies involved in their legislative harmonisation. How can we ensure that (a) the issue of civil liability is addressed in a more coordinated fashion across different sectors of financial services and activities, and that (b) the various actors involved in the enforcement of EU financial regulation, notably civil courts, ADR bodies, and financial regulators, better coordinate their actions? And what can be done at EU and national level to address the shortcomings of the current state of play?

\subsection{EU Level}

On a more general note, the role of civil liability in financial regulation, both as a deterrent and compensatory mechanism, deserves much more attention in the EU law-making than has been the case so far. As the bottom-up analysis of the interplay between EU financial regulation and national law in this chapter suggests, the legal grammar of a particular EU measure does matter in practice when it comes to the position of private parties in case of breach of European regulatory standards and the CJEU's ability and willingness to engage in judicial activism to improve this position. Once a certain piece of EU secondary law is adopted, the availability of individual rights and remedies for private parties in various legal systems will to an important degree be determined by the particular balance of public and private law elements that have emerged from the EU's legislative itinerary. When making European financial law, therefore, the EU legislator should stop ignoring the existing differences between public and private law approaches and become more sensitive to the type of legal grammar that it intends to use, thus building a stronger connection with national legal systems. Rediscovering the public/private law divide in this sense does not mean redrawing the strict line between public and private law. As this chapter has shown, the dividing line between public and private law has indeed been blurred, with private law being used as an instrument of European market integration, and the public and private spheres and enforcement modes in the field of European financial law becoming ever more closely intertwined. However, the rise of hybrid phenomena in the context of a post-nation-state European financial law does not mean that we should get rid of the public/ private dichotomy altogether as the irrelevant legacy of the nation-state. As Armin von Bogdandy remarked when exploring the idea of contemporary European public law, 'any observation of hybridity requires an understanding 
of the individual components that render something hybrid; a hybrid car is a car that uses combustion engine and an electric motor, and a mule is a cross between a horse and a donkey'. ${ }^{116}$ In my view, this is particularly true for European financial law. The EU's experimentation with the 'public' and 'private law' grammar options in this area makes it an interesting laboratory. But in order to be able to experiment, one had better understand what one is actually experimenting with.

The public/private distinction can perform a useful function in the making of European financial law, allowing us to describe and analyse two different but related regulatory strategies. ${ }^{117}$ The acknowledgement of this distinction for descriptive and analytical purposes should lead to more evidence-based law-making at EU level, which would enable the EU legislator to assess the relative merits of each model (or a combination of the two) more accurately, and to ultimately choose the one most suited to pursuing a particular policy goal. Improving the law-making along these lines would fit into the EU's Better Regulation agenda, ${ }^{118}$ which should be seen as an opportunity to critically rethink the current enforcement architecture in the field of European financial law and the role of civil liability therein. Better EU financial regulation does not necessarily mean 'more Europe' in the remedial domain, but, first and foremost, a more nuanced and complete understanding of different 'legal grammar' options for EU harmonisation measures, informed by multiple perspectives. As the chapters in this book show, such understanding is essential for developing a more coordinated approach to financial regulation and civil liability at EU level, across both different sectors of financial services and activities, and enforcement actors.

For instance, at least three different perspectives point out that a civil liability rule in MiFID II would have an added value and that the striking difference in legal grammar between this directive and PSD2 is therefore unjustified. First, this follows from the law and economics analysis of enforcement in the fields of payment and investment services by Michael Faure and Franzisca Weber, noted above. Their analysis reveals that to ensure sufficient deterrent effect, private enforcement through civil liability rights could be the primary enforcement mode in both areas and would need to be combined with public enforcement, particularly through administrative law means. As Agnieszka

116 A. von Bogdandy, 'The Idea of European Public Law Today' in A. von Bogdandy et al. (eds), The Max Planck Handbooks in European Public Law (Vol. 1, OUP 2017) 1, at 13.

117 Cf., H. Muir Watt \& F. Cafaggi, 'Introduction' in F. Cafaggi \& H. Muir Watt (eds), The Regulatory Function of European Private Law (Edward Elgar Publishing 2009) $x$, at xii.

118 European Commission, Better Regulation Guidelines, SWD(2017) 350. 
Janczuk-Gorywoda shows in her chapter, PSD2 puts in place such a smart mix, exploiting comparative advantages of each mechanism to enhance the effectiveness of EU payments law. An extensive set of European private law rights of payment service users forms an integral part of the directive's private enforcement mechanism, enabling consumers to harness its potential. From the law and economics perspective, a similar approach to bolster private enforcement would also be appropriate in the case of MiFID II. As Faure and Weber observe, losses resulting from breaches of regulatory standards can be potentially high, creating an important incentive for both professional and retail investors to sue. The problem of establishing a breach of such standards, which can present particular difficulties for retail investors, could be addressed by allowing them to rely on a finding of such infringement by an administrative agency.

Second, a significant role of civil liability within the regulatory framework established by MiFID II is also highlighted by Yane Svetiev, who analyses it from an experimentalist governance perspective, ${ }^{119}$ focussing on product governance. In his view, it is useful to understand the emerging product governance regimes in experimentalist terms, given the inherent uncertainty about the effectiveness of the means used to achieve desired policy outcomes as well as enforcement constraints. The MiFID II product governance regime focuses on prevention of harm through the detection of incipient problems rather than ex post compensation as a deterrence mechanism. Yet, a civil liability regime could complement this experimentalist regime by providing not only an additional incentive for financial institutions to make the required product governance arrangements in the first place, but also a further avenue for problem detection. After all, even where such arrangements have been put in place, investment firms and financial regulators may fail to discover problematic investment products and prevent harm. Private damages claims by aggrieved investors, which are not contingent on a prior decision by a financial regulator, would generate diversity in enforcement pathways, reducing the risks of regulatory monoculture. Instead of treating ex ante regulation and ex post litigation as substitutes, therefore, an experimentalist approach seeks to combine internal product governance processes, regulatory action, and private damages claims in order to detect problems and provide for innovative solutions. Civil liability could thus play an important role in ensuring that investment products are appropriately designed and distributed and do not cause harm to investors, particularly in the retail markets.

119 On the merits, see, e.g., C. Sabel and J. Zeitlin, 'Learning from Difference: The New Architecture of Experimentalist Governance in the EU' (2008) 14 ELJ 271, at 280. 
Third, the added value of a civil liability rule in MiFID II becomes particularly clear from Marnix Wallinga's comparative legal analysis of private law remedies for breach of the conduct of business rules laid down in this directive. Many such rules, such as the duty to know one's customer, originated in the traditional private laws of the Member States. ${ }^{120}$ As mentioned earlier, however, some national civil courts, notably the German Supreme Court, have been reluctant to give effect to these regulatory standards with a European origin in private law. This may suggest that the MiFID II's and its predecessor's silence on the issue of civil liability rights has led to the private enforcement deficit in some legal systems. As Wallinga observes, an express provision on civil liability for breach of the MiFID II conduct of business rules would ensure that investors are entitled to hold investment firms liable for the losses suffered, regardless of their national private law's stance on this issue, thus facilitating private enforcement. For example, an EU rule to this effect could preclude the German Supreme Court from blocking recourse to non-contractual liability for breach of a statutory duty, especially where investors cannot rely on contractual liability for breach of the firms' duties of care. Further, a civil liability rule in MiFID II could also require a reversal of the burden to prove a causal link between the breach of the conduct of business rules and the damage in favour of retail investors if the latter would otherwise be unable to effectively invoke this European remedy. At the same time, Wallinga warns against introducing a fully harmonised civil liability regime at EU level since it could prevent national civil courts from doing justice in individual cases.

This three-dimensional analysis suggests that the EU legislator should be more mindful towards the role of civil liability and other private law remedies in regulatory and enforcement design for a particular area of financial services and activities, as well as across such areas. Explicit European civil liability rights could play a particularly important role in those fields where financial consumer/investor protection is at stake and private enforcement is essential. As the example of MiFID II illustrates, remaining silent on the issue of civil liability in such an area may not be the best solution, especially when the EU legislator explicitly prescribes a public enforcement mechanism. Where legislative intervention to strengthen private enforcement at EU level is appropriate, different regulatory options involving varying degrees of the national remedies' hybridity should be considered. Solutions may range from a general reference to national law, such as the one in the Prospectus Regulation (the second category of Takis Tridimas' classification) to a relatively autonomous European regime of private law rights and remedies, such as the one in PSD2 (the third

120 For Germany, cf., e.g., BGH 6 July 1993, BGHZ 123, $126=$ NJW 1993, 2433 (Bond). 
category of Tridimas' classification). When considering different regulatory options, previous experiences with harmonised civil liability rules within and outside a particular area need to be taken into account. The bottom-up analysis of EU financial regulation could prove particularly useful in this context, facilitating cross-sector learning. For instance, as Francesco de Pascalis shows in his chapter, without further adjustment to improve the investors' procedural position, the current civil liability regime of the CRA Regulation is likely to remain a paper tiger. By contrast, Agnieszka Janczuk-Gorywoda's analysis highlights the success of the PSD2's civil liability regime, combined with administrative enforcement, in increasing the effectiveness of EU payments law. At the same time, the EU legislator must be wary of a 'one-size-fits-all' approach. In his chapter, Federico Della Negra warns against adopting such an approach in the securities field since it would inevitably fail to capture the specificities of each market sector (e.g., primary and secondary markets), as well as the investors (e.g., professional and retail) and the financial institutions (e.g., issuers, intermediaries, gatekeepers) concerned. Different factors may be decisive, for example, when designing civil liability regimes for the retail and wholesale securities sectors. While in the former case a risk of underenforcement by retail investors should be given particular weight, in the latter case one should not overlook the relative sophistication of the contracting parties, and the need to preserve legal and commercial certainty.

Furthermore, the EU could play a far greater role in the development of coordination between the different actors involved in the enforcement of financial regulation. The foregoing analysis has revealed that such coordination currently remains underdeveloped, particularly with respect to the sequentiality of enforcement actions and the legal status of the previous enforcers' final decisions. This raises serious doubts about the effectiveness, proportionality, and dissuasiveness of the combined public and private enforcement mechanisms. In order to address the problem of insufficient coordination in enforcement, these three requirements should be observed not only within one particular enforcement mechanism (either public, private, or hybrid), but also across such mechanisms. ${ }^{121}$ The EU legislator and, in the absence of legislative action, the CJEU should guide national legislators and dispute resolution bodies in applying the triad accordingly and resolving potential conflicts between different requirements, especially where deterrence is pursued through both public and private law means. That the EU legislator can take the lead in such matters is evidenced by its proactive stance on the application of administrative law sanctions for infringements of EU financial regulation. It is striking that some EU measures in the field of financial law not only harmonise such sanctions,

121 Cf. Cafaggi \& Iamiceli (n. 2) at 617. 
but also specify the circumstances that must be considered by administrative authorities when determining their type and level. While the lists of such factors are not intended to be exhaustive, they do shed light on the issue of how financial regulators may comply with the requirements of effectiveness, proportionality, and dissuasiveness within an administrative enforcement mechanism. ${ }^{122}$ However, there is hardly any such guidance on the application of private law remedies in the financial sector, either alone or in combination with public law sanctions. ${ }^{123}$

In particular, to enhance private enforcement in those areas where aggrieved individuals are effectively unable to establish an infringement of regulatory standards, EU legislation could allow them to rely in civil proceedings on the financial regulators' findings of such infringement. For instance, drawing on experience in the field of competition law, such a coordinated mechanism could be inserted in the CRA Regulation. This could increase the effectiveness of the civil liability rule enshrined in this EU measure and provide an effective remedy for aggrieved investors to which they are also entitled under Article 47 of the Charter of Fundamental Rights of the European Union. The findings by Chiara Picciau and Federico de Pascalis in their chapters in this volume point to the pressing need for such a solution.

In addition, where both public and private enforcement mechanisms are used to deter infringements in one and the same field, the CJEU could play an important role in raising awareness at national level about the general purport of the principles of effectiveness, proportionality, and dissuasiveness in this context. As noted above, the CJEU currently appears to be reluctant to apply these requirements across different enforcement mechanisms. Yet, Reinhard Steennot's analysis in this volume reveals that the accumulation of administrative sanctions and private law remedies may result in the imposition of disproportionate penalties on creditors and credit intermediaries, giving rise to knotty questions about the relationship between dissuasiveness and proportionality in the field of EU consumer credit law and beyond.

Further, the EU legislator could foster not only the involvement of financial regulators in collective consumer redress, but also coordination of such hybrid enforcement actions with the actions of civil courts and ADR bodies. As Antonio Marcacci shows in his chapter in this volume, the experience of the US Securities and Exchange Commission (SEC) with the enforcement of investor protection regulation at federal level could provide a source of inspi-

122 See, e.g., MiFID II, art. 72(2); EMIR, art. 65(2)-(4); Prospectus Regulation, art. 39(1). See also European Commission, 'Reinforcing Sanctioning Regimes in the Financial Services Sector', COM(2010) 716 final.

123 On similar problems in the field of EU consumer law, see Pavillon (n. 26). 
ration for ESMA. In particular, SEC may choose either to bring civil action in federal court, to initiate administrative proceedings before an administrative law judge, or both. This hybrid mechanism ensures that private law remedies and administrative law sanctions are formally kept separate, but can nevertheless be applied in a coordinated manner by SEC to ensure both compensation and deterrence in case of breach of regulatory standards. Marcacci points out that the current institutional set-up does not allow ESMA to act in a similar way. However, what ESMA and other ESAs can already do to ensure better coordination between public and private enforcement is to harness the data on intra-firm complaints-handling procedures as well as private adjudication, particularly before ADR bodies, when exercising their supervisory powers.

Finally, beyond the cross-sector and cross-actor aspects explored in detail above, a coordinated approach to EU financial regulation and civil liability can also be understood in a more 'meta' sense, involving the role of civil liability in ensuring the proper functioning of the institutions responsible for financial supervision and dispute resolution in the EU. In her chapter in this volume, Elena Sedano Varo explores the potential for the civil liability of EU institutions in respect of failures in the exercise of their supervisory and resolution powers in the context of the Banking Union, focussing on a regulatory framework for contingent convertible bonds (CoCos). These highly sophisticated financial instruments have gained much attraction in the wake of the financial crisis as 'bail-in' tools to increase the quantity and quality of bank capital, and thus inhibit risk transfer from debt holders to tax payers ('bail-out') in the future. Potentially high returns have made CoCos an attractive investment for institutional investors, such as hedge funds, asset managers, and pension funds. At the same time, the EU regulatory framework for these financial instruments has opened up new avenues for the financial regulators' civil liability for defective banking supervision. In particular, Sedano Varo's analysis reveals that in case of the bank's non-compliance with capital requirements (as specified in the EBA's technical standards) and subsequent resolution, the ECB, the $\mathrm{SRB}$, and the European Commission can be held liable to aggrieved investors for negligence under Article 340 TFEU. The prospect of this non-contractual liability could not only allow the investors to obtain compensation for the losses suffered, but also enhance the quality of financial supervision in the Banking Union. However, as Sedano Varo points out, this new avenue for civil liability could jeopardise the transition from bail-out to bail-in pursued by the EU since the taxpayer would once again have to step in to pay the bill.

In a similar vein, the outsourcing of financial consumer disputes to ADR entities fostered by the EU raises the question of their civil liability. In her chapter in this volume, Barbara Warwas argues that so far not enough has been done to ensure that ADR bodies - which can be public, private, or mixed - do not abuse their position vis-à-vis consumers. The lack of the ADR entities' 
accountability to both public authorities and parties to disputes undermines consumer trust in the financial sector that the EU has sought to restore in the aftermath of the financial crisis. In particular, private ADR bodies are now generally exempt from civil liability. According to Warwas, one solution to enhance the accountability of private ADR entities is to have them assume liability for the performance of contractual services through self-regulation. Public regulation in turn should require such entities to purchase liability insurance. The EU should encourage Member States to put such a mixed public/ private regulatory framework in place, given a shared responsibility to ensure the proper functioning of ADR systems and consumer access to justice.

\subsection{National Level}

While the EU could thus play a significant role in fostering better coordination between financial regulation and civil liability, the national legal orders of the Member States remain crucial in ensuring such coordination. First of all, insufficient 'empathy' of EU financial regulation towards the private law side of private conduct that it seeks to steer and its inherent incompleteness, notably with respect to private law remedies, highlight the importance of national law in remedying the interpersonal justice deficit in EU law, thus increasing its effectiveness. A particularly important role in this context can be assumed by national civil courts and ADR bodies which are in a position to enable private litigants to act as integration agents even without being expressly prompted by the EU legislator or the CJEU. In order to unpack the potential of private enforcement to contribute to the policy objectives pursued by the EU legislator in the financial sector, we need to look at national private law through the European 'regulatory' lens and conceptualise its relationship to EU financial regulation. ${ }^{124}$

Such a conceptualisation is particularly needed in the context of the predominantly public law-oriented EU measures, such as the MiFID I and MiFID II discussed above. While such measures aim to protect certain categories of market participants (e.g., investors), they nevertheless fall short of providing a minimum European level of individual protection under private law. Even in the absence of an unequivocal obligation to this effect under EU law, however, national civil courts could address the lack of European private law remedies for breaches of regulatory conduct of business rules through private adjudication, thus ensuring better coordination with respect to such remedies across different sectors of financial services and activities. In particular, civil courts could develop a complementary relationship between the "public

\footnotetext{
124 Cherednychenko (n. 25).
} 
law'-coloured EU financial regulation, also known as the European financial supervision private law, noted above, and national private law. ${ }^{125}$ Such a relationship implies that when establishing the standard of care in private law, courts should consider the EU conduct of business rules that have become part of a national financial supervision framework. In other words, the ex ante regulatory standards of financial firms' conduct should be taken into account when reviewing their behaviour towards (potential) customers ex post on the basis of general private law norms. Yet, the complementarity between EU financial regulation and national private law does not preclude civil courts from imposing more protective duties on financial firms in private law. ${ }^{126}$ Such an approach is manifest, for example, in the case law of the Dutch and English courts, ${ }^{127}$ discussed by Marnix Wallinga in his chapter. The Dutch Supreme Court (Hoge Raad) has ruled that there is a two-tier system of duties of care for financial firms in Dutch law - public law duties and private law duties; while the public law duties influence the private law duties, the former do not determine the latter. An aggrieved customer may thus invoke regulatory conduct of business rules in support of his or her private law claim. At the same time, the defendant financial firm cannot successfully contend that because it has complied with the applicable regulatory duty, it has also discharged its duty of care in private law. After all, private law concepts act as mediators of the effect of regulatory standards in private law relationships. The complementarity between financial regulation and civil liability in this sense is also supported by Yane Svetiev's experimentalist analysis, which shows that in order to maintain multiple avenues for detecting problems in financial markets, civil redress should not be entirely contingent on public intervention.

Moreover, under the complementarity model, as Wallinga argues in his chapter, EU financial regulation may influence not only private law duties of care, but also rules of civil procedure. The latter often pose considerable obstacles to aggrieved customers on the way to redress. In the context of MiFID I and MiFID II, for instance, retail investors typically struggle to estab-

125 On this in more detail, see O.O. Cherednychenko, 'Contract Governance in the EU: Conceptualising the Relationship between Investor Protection Regulation and Private Law' (2015) 21 ELJ 500, at 513.

126 This idea of complementarity between the public law-oriented EU financial regulation and private law thus does not support the view expressed by some authors that because MiFID I provides for maximum harmonisation of regulatory conduct of business rules for investment firms, Member States are not allowed to maintain or introduce stricter duties for such firms in national private law. See, e.g., P.O. Mülbert, 'The Eclipse of Contract Law in the Investment Firm-Client-Relationship' in G. Ferrarini \& E. Wymeersch (eds), Investor Protection in Europe: Corporate Law Making, the MiFID and Beyond (OUP 2006) 299, at 318.

127 See the case law in n. 41. 
lish a causal link between the breach of the applicable standard of care by an investment firm and the damage sustained by them (a condicio sine qua non relationship). When faced with a claim for damages, investment firms often contend that even if they had, for example, properly informed or advised the client, he or she would have taken the same investment decision anyhow. As MiFID I and MiFID II do not contain any rules on the burden of proof in case of breach of the conduct of business rules, it depends on national private laws whether and, if so, how evidential problems will be alleviated. However, in line with the idea of complementarity, the conduct of business regime embodied in these directives, and the underlying goal of investor protection, could influence private law rules on causation, prompting national civil courts to reverse the burden of proof between the breach of the standard of care and the damage suffered in favour of retail investors or to lower the standard of proof concerning such a link. This would not only assist retail investors in obtaining redress, but would also foster the investor protection pursued by MiFID I and MiFID II.

The embrace of a complementary relationship between the 'public law'-coloured EU financial regulation and national private law would thus urge civil courts and other dispute resolution bodies to openly consider regulatory expertise when interpreting and applying traditional private law concepts in individual cases. This would enable them to modernise the traditional categories of national private law in order to develop an appropriate remedial response to breaches of regulatory standards, and thus contribute to the achievement of the underlying EU policy objectives. ${ }^{128}$ At the same time, the complementarity model would not eliminate the autonomy of national private law and private law adjudication from regulatory and supervisory measures. Such autonomy is particularly important today, given the growing standardisation of retail financial market governance through post-crisis EU measures, coupled with their increasingly technocratic quality, notably through ESMA's activities. ${ }^{129}$ This trend is evident in the emergence of immensely detailed European regulatory standards on how firms should approach their engagement with retail financial markets. These standards leave national financial regulators with little room for manoeuvre, impairing their ability to secure good retail market outcomes geared to local market circumstances. In addition, over-reliance on prescriptive ex ante regulatory rules by national dispute

128 Cf., M. Andenas, 'Commercial Law, Investor Protection, EU and Domestic Law' in M. Heidemann and J. Lee (eds), The Future of the Commercial Contract in Scholarship and Law Reform: European and Comparative Perspective (Springer 2018) 437, at 467.

129 On this in more detail, see N. Moloney, 'EU Financial Market Governance and the Retail Investor: Reflections at an Inflection Point' (2018) 37 YEL 251, at 283. 
resolution bodies may preclude such bodies from ensuring justice between the parties to an individual dispute. This in turn would undermine the potential of national private law systems to act as laboratories in which problems in financial markets can be detected and adequately addressed ex post.

By developing a complementary relationship between EU financial regulation and private law, national dispute resolution bodies could thus 'upgrade' the public law-oriented EU measures, such as MiFID I and MiFID II, with the interpersonal dimension which is currently missing therein. But the idea of a dialogue between European supervision private law and traditional national private law enshrined in the complementarity model could also prove useful in other contexts, especially where the individual protection provided by a particular EU measure is weak, as in the case of the CRA Regulation. We have noted already that a harmonised extra-contractual liability regime for credit rating agencies is designed to facilitate investor redress in cases where there is no contractual relationship between a credit rating agency and an investor. It is here that the national private laws of the Member States were considered to be insufficient, providing a justification for the EU action. Paradoxically, however, without further action at national level, the European remedy for investors created by the CRA Regulation risks remaining a dead letter, given the enormous civil procedural hurdles associated with it that investors need to overcome to obtain compensation. Not only does the investor need to establish that the credit rating agency has committed one of the infringements listed in the CRA Regulation, in addition the investor must demonstrate 'that infringement had an impact on the credit rating issued' 130 and that 'it has reasonably relied, in accordance with Article 5a(1) or otherwise with due care, on a credit rating for a decision to invest into, hold onto or divest from a financial instrument covered by that credit rating'. ${ }^{131}$ As Chiara Picciau observes in her chapter, it is generally very difficult, if not impossible, for investors to discharge the burden of proof with regard to these requirements. In the absence of the EU rules on this matter, whether investors will succeed in establishing (a) the violation of the CRA Regulation by the credit rating agency and (b) the causal link between the violation and the damage suffered in terms of (i) the investor's reliance on the credit rating and (ii) the impact of the violation on that rating largely depends on the willingness of national civil courts to alleviate the evidential problems.

In fact, the possibility for the courts to do so when it comes to establishing the infringement of the relevant rules is provided by the CRA Regulation itself. The latter obliges national courts to assess for this purpose "what constitutes

130 CRA Regulation, art. 35a(2).

131 Ibid., art. 35a(1). 
accurate and detailed information', 'taking into consideration that the investor ... may not have access to information which is purely within the sphere of the credit rating agency'. ${ }^{132}$ To address this problem in line with the idea of complementarity between European supervision private law and national private law, national courts could allow investors, for instance, to rely on the decision of ESMA establishing the infringement of the CRA Regulation in civil proceedings. Further, when an investor brings a claim against a credit rating agency based on national tort law - which is not precluded by the CRA Regulation $-{ }^{133}$ courts could enable him or her to establish causation based on factors other than the investor's reliance on a credit rating. For example, in the light of the US experience, Picciau argues that investors could simply be allowed to demonstrate that the inaccurate credit rating has distorted the price of securities or that it has been a necessary precondition for offering securities on the primary market. Such a solution could be achieved through the interpretation of national tort law in the light of the investor protection objective of the CRA Regulation, making it possible for investors to indirectly circumvent the problematic requirement of reliance under Article 35a. The development of a complementary relationship between EU financial regulation and national private law along these lines would thus enable the latter to contribute to the achievement of the regulatory objectives pursued by the EU legislator beyond what is strictly required by EU law, while at the same time ensuring justice between the parties to an individual dispute. Mutual learning between financial regulators and private adjudicators across different jurisdictions within and outside the EU could facilitate the adoption of such an approach. The above analysis provides several examples from the Member States which require some form of coordination between civil and administrative actions to facilitate civil redress.

Furthermore, this idea of complementarity between EU financial regulation and national private law could also be broadened to include coordination across public, private, and hybrid enforcement mechanisms at national level with a view to ensuring compliance with the requirements of effectiveness, proportionality, and dissuasiveness, as well as legal certainty. As Reinhard Steennot observes in his chapter focussing on consumer and mortgage credit, in the absence of EU guidance, national legislators should determine how the public and private enforcement mechanisms interact, especially where both aim at deterring infringements. In addition, cross-actor coordination is essential where financial regulators are empowered to pursue not only deterrence, but also compensation in mass damage cases. National legislation granting such

132 Ibid., art. 35a(2).

133 Ibid., art. 35a(5). 
powers should also provide for the coordination of hybrid enforcement actions by financial regulators with the actions of civil courts and ADR entities. The coordination mechanism accompanying the UK FCA's powers with respect to a consumer redress scheme, noted above, provides an instructive example of a legislative design of such a mechanism. Innovation in enforcement modes should thus go hand in hand with innovation in cross-actor cooperation.

\subsection{Outlook}

This book explores the intricate interplay between financial regulation and civil liability in European law, combining top- and bottom-up comparative legal analysis, law and economics, and experimentalist governance. The study shows that, overall, a coordinated approach to this interplay is currently lacking, both at EU and national level, and outlines directions for such an approach to develop more fully across different sectors of financial services and activities, and enforcement actors. A persistent theme in the chapters concerns suggestions for understanding and improving the precise engineering and design details of the construction of the bridge between financial regulation and civil liability by the EU and its Member States. The findings of the study highlight the need to fundamentally rethink the role of civil liability, and private law remedies more generally, as a regulatory and compensatory tool in European financial law. A more coordinated approach to EU financial regulation and private law remedies would break down the boundaries between public and private law, viewing these two areas of law as distinct but closely interrelated. Further research is needed to be able to design an appropriate coordination between public regulation and civil liability in each individual area of financial law, and across different enforcement mechanisms, taking into account the big societal challenges that the financial sector is facing today. ${ }^{134}$ Among such challenges are climate change mitigation, a switch to a resource-efficient circular economy, the digitalisation of the marketplace and societies at large (in particular through the use of such technologies as digital platforms, Big Data analytics, artificial intelligence (AI), and blockchain), and, last but not least, the COVID-19 crisis. Most crucially, this volume sets out an analytical framework - with both theoretical and empirical components - for further inquiry into the interface between financial regulation and private law remedies in the EU multi-level system of governance. This framework offers

134 For some preliminary research on the interplay between EU retail financial regulation and contract law in the context of such challenges, see O.O. Cherednychenko, 'EU Financial Regulation, Contract Law and Sustainable Consumer Finance' in E. van Schagen \& S. Weatherill (eds), Better Regulation in EU Contract Law: The Fitness Check and the New Deal for Consumers (Hart 2019) 61. 
a sound foundation for a more systematic analysis of the current legal regimes in particular areas and developing the new ones to underpin further research and policy-making on this complex but fascinating subject. 